\title{
COMMENT
}

\section{SHOULD TENDER OFFER ARBITRAGE BE REGULATED?}

Arbitrageurs, often viewed as "vague shadows with European backgrounds," are silently at work in most tender offers, in many cases controlling their outcome. This Comment will examine the activities of tender offer arbitrageurs, which are presently unregulated, and will explore the need for new regulations to restore a balance to the tender offer process.

The Comment first reviews the origins and development of arbitrage in its various forms and then focuses upon the mechanics of arbitrage in the specific context of the tender offer process. The arguments traditionally advanced in justification of the role of arbitrage in tender offers are then critically examined in light of the theory of efficient capital markets, the present imbalance of tender offer regulation and the long-term economic effects of tender offer arbitrage as it is currently practiced. Finally, the Comment seeks to provide a focal point for future debate by suggesting an approach to be taken in developing an effective system to regulate the role of arbitrage in the tender offer process.

\section{The Mechanics and Development of ARbitrage}

\section{A. The Classic Forms of Arbitrage.}

The term "arbitrage" is derived from the French verb "arbitrer,"

THE FOLLOWING CITATIONS WILL BE USED IN THIS COMMENT:

E. ARANOW \& H. EINHORN, TENDER OfFERS FOR CORPORATE CONTROL (1973) [hereinafter cited as ARANOW \& EINHORN];

E. Aranow, H. Einhorn \& G. Berlstein, Developments in Tender Offers for CorpoRATE CONTROL (1977) [hereinafter cited as ARANOW, EINHORN \& BERLSTEIN];

M. Evans, ARbitrage in Domestic Securities IN the UNited STATES (1965) [hereinafter cited as EVANS];

J. Lorie \& M. HAMILTon, THE Stock MARKeT: Theories AND EvidenCE (1973) [hereinafter cited as LORIE \& HAMILTON];

Henry, Activities of Arbitrageurs in Tender Offers, 119 U. PA. L. REv. 466 (1971) [hereinafter cited as Henryl;

Wyser-Pratte, Risk Arbitrage, BulletiN, May 1971 (N.Y.U. C.J. Devine Institute of Finance) [hereinafter cited as Wyser-Pratte];

Note, The Efficient Capital Market Hypothesis, Economic Theory and the Regulation of the Securities Industry, 29 STAN. L. REv. 1031 (1977) [hereinafter cited as Stanford Note].

1. Huge Profits Out of Tiny Margins, Bus. WEEK, May 28, 1966, at 114. 
meaning "to measure, determine, judge or estimate."2 In financial circles, arbitrage is the science of measuring and comparing price differentials and exploiting them for a profit. In an elementary sense, everyone is an arbitrageur. When the thrifty shopper compares grocery prices to maximize his shopping dollar, he engages in arbitrage in its most basic form.

Arbitrage in the "classic" sense was first observed in the late medieval period among Venetian merchants, who bought and sold interchangeable currencies in order to profit from price differentials prevailing between markets. ${ }^{3}$ A refined version of this classic form of arbitrage, which is still practiced on international money markets, has been facilitated by the development of better-organized markets and highly sophisticated communications networks. ${ }^{4}$

In the past century, the growth of the securities market in the United States and the increasing use and popularity of various types of convertible securities ${ }^{5}$ have led to a further application of the arbitrage principle. Unlike arbitrage in currencies, this newer form of arbitrage relies for its success not upon price differentials between markets, but upon differentials between parities of equivalent securities ${ }^{6}$ in the same market. ${ }^{7}$ This form of arbitrage normally involves the simultaneous purchase of a convertible security with the short sale ${ }^{8}$ of its equivalent. The arbitrageur looks for convertible securities whose equivalents have parities $^{9}$ in excess of the current market value of the convertible securi-

2. See H. Deutsch, Arbitrage 1 (3d ed. 1933); M. Weinstein, Arbitrage in SecuriTIEs 1 (1st ed. 1931). See generally 1 The OXFord ENGlish Dictionary 425 (1933) (discussion of the word "arbitrage" and its origins).

3. M. Weinstern, supra note 2, at 3-6; Wyser-Pratte 7 .

4. Wyster-Pratte 7-8.

5. A convertible security is a security which, by its terms, may be exchanged for another security in accordance with a specified formula. Examples of such securities include rights, warrants, convertible bonds, convertible debentures and convertible preferred stock.

6. A security has as its equivalent a second security if the holder of the first security has the option of exchanging or converting it into a specified amount of the second security. This is typically a one-way process, unlike the convertibility of currencies in foreign exchange markets. EVANS 22; M. WeINSTEIN, supra note 2, at 66-67; Henry 467.

7. Evans 21 ; Wyser-Pratte 8.

8. "Selling short" involves the sale of securities which one does not presently own. Shares are borrowed, at a fee, for delivery to the purchaser, and the trader must subsequently "cover" his short position by purchasing like securities which are returned to the lender. See Henry 467 n.8.

9. "Parity" denotes the total or "work-out" value of a particular package of securities equivalent to a given security. For example, if the Class $A$ 4-1/2\% subordinated debentures of $X$ corporation, presently selling at $\$ 1,000$, are convertible into $X$ common and preferred stock at a ratio of 17 shares of common and 7.2 shares of preferred per debenture, and if current market prices for common and preferred are, respectively, $\$ 37.25$ and $\$ 52.75$, then parity value for the equivalent of one $\$ 1,000$ debenture is $(17 \times 37.25)+(7.2 \times 52.75)=\$ 1,013$. For a more exhaustive discussion of parity computation, replete with examples, see Wyser-Pratte 15-16, 75-87. 
ties. ${ }^{10}$ He then buys long in a convertible security, sells short the equivalent, converts his holdings and covers his short sale, realizing a profit after brokerage and specialist fees (if any), transfer taxes, SEC fees and the cost of capital. ${ }^{11}$

The price differentials exploited by this form of arbitrage do not persist for long and usually represent only temporary lags on the part of the covertible security in catching up with changes in the price of its equivalent. Moreover, the price differential is usually so small as to make this form of arbitrage profitable only for those who can deal in volume with low transaction costs.

B. The Evolution of Risk Arbitrage.

)

Both types of arbitrage mentioned above are relatively riskless. ${ }^{12}$ Since the purchases and sales involved take place simultaneously, the arbitrageur locks in his profit margin and runs no risk of setbacks due to market fluctuations. For that reason, however, the profit margin in such transactions is seldom large. ${ }^{13}$ The real opportunity for profit lies with risk arbitrage. ${ }^{14}$

The development of risk arbitrage in the United States can be traced primarily to the numerous railroad reorganizations that occurred in the late 1930s and early 1940s as a result of the Depression. ${ }^{15}$ Typically, the plan for such a reorganization provided for the exchange of existing equity and debt securities for packages of newly issued securities containing such diverse elements as common stock, preferred stock, bonds, debentures, warrants and rights. ${ }^{16}$ Inherent in these reor-

10. Evans 25.

11. Id 25-27; ARANOW \& EINHoRn 175-76; Henry 467.

12. ARANOW \& EINHORN 174.

13. See Wall Street's Highest Rollers, Trme, Oct. 17, 1977, at 54, where it is noted that classic or riskless arbitrage is still practiced, but that profits are "tiny." This is a corollary of the fundamental proposition that large returns are normally associated with greater risks. See notes 77-80 infra and text accompanying notes 77-83 infra for a discussion of risk in the related context of security price formation.

14. Id See Ehrbar, How to Play the Arbitrage Game, ForTune, July 1976, at 83 (discussing arbitrageur profits on several mergers, $i d$. 83-86, and observing that arbitrageur profits are "immense when computed at annual rates," id. 84); Hershman, Arbitrage-Headiest Game in the Street, DuN's REV., June 1969, at 52 (some risk arbitrageurs made profits exceeding 100\% per year and that "if the risk is high, so is the potential return," id.); Tracy, $A$ Killing in Babcock \& Wilcox, FoRTuNe, Oct. 1977, at 266 (explaining how arbitrageurs made more than $\$ 30$ million during the recent takeover of Babcock and Wilcox by McDermott); Arbitrage: It's the Hottest Game in Town, Bus. WEEK, Jan. 17, 1977, at 71 (describing the large profits made by various risk arbitrageurs on mergers and acquisitions in 1976 and noting that "[t]he potential for profit in risk arbitrage is enormous," $i d$ ).

15. ARANOW \& EINHORN 176; Wyser-Pratte 8.

16. See, e.g., EvANs, giving examples of typical railroad reorganization schemes and discussing the arbitrageur's role. Id. 24-25. The author shows how to construct a table of "related 
ganization plans was the risk of nonapproval by either shareholders, creditors, ${ }^{17}$ a federal court ${ }^{18}$ or the Interstate Commerce Commission. ${ }^{19}$ This element of risk resulted in a market where, prior to final approval of the reorganization plan, existing securities traded lower than the parity value of the proposed package of securities traded on a "when-issued" basis. ${ }^{20}$ Arbitrageurs willing to assume this risk were able to reap large profits.

A second important impetus for the development of risk arbitrage was the 1935 Public Utility Holding Company Act. ${ }^{21}$ The Act required many public utilities to divest themselves of subsidiary holdings. ${ }^{22}$ Consequently, markets developed for the newly proposed issues of stock on a "when-issued" basis. An arbitrageur adept at gauging the effect of divestiture on parent company stock prices and willing to assume the attendant risks could profit where the parity value of the "when-issued" package plus the projected value of parent company stock after the distribution exceeded the before-distribution price of parent company stock.

A more recent opportunity for application of the risk arbitrage

values" for such a transaction, id. $43-46$, and discusses problems of supply and demand which may arise, id. 69-74.

17. A railroad reorganization plan, to become effective under Chapter VIII of the Bankruptcy Act, ordinarily must be approved by creditors whose claims constitute at least two-thirds in value of all claims against the debtor and, if the debtor is solvent, by a majority of the shareholders of each class of stock to which the plan must be submitted. Bankruptcy Act $\$ 77(\mathrm{e}), 11$ U.S.C. $\S 205$ (e) (1970). However, a federal district court judge may, in certain cases, confirm the plan despite shareholder or creditor disapproval, where those who rejected the plan will receive "fair and equitable" treatment and where such rejection is not reasonably justified in the light of all relevant facts and surrounding circumstances. $I d$.

18. A federal district court, before approving a railroad reorganization plan, must find, inter alia, that the plan conforms to the provisions of the Bankruptcy Act, is "fair and equitable" and does not discriminate unfairly against any of the various classes of affected creditors and shareholders. Id.

19. The Interstate Commerce Commission has extensive control over a proposed plan of reorganization. For example, the Commission must hold public hearings on the plan and subsequently render a report either approving the proposed plan, or a modified version thereof, or in some cases refusing to approve any plan. Approval and certification by the Commission are necessary before the district court can proceed to approve and/or confirm the plan. Bankruptcy Act $\S 77(d), 11$ U.S.C. $\S 205$ (d) (1970).

20. ARANOW \& EINHORN 176; Wyser-Pratte 8. "'When-issued trading' is trading in unissued securities which is effected in contemplation of their issuance; a dealer simply makes a contract to sell the securities to another dealer or to an ordinary customer 'when, as and if issued." 1 L. Loss, Securities Regulation 221 (2d ed. 1961). "When-issued" trading is similar in many respects to short sales of securities and to futures trading on the commodities market. It is subject to relatively complex regulation, and in some cases prohibition, under the various securities laws, SEC regulations and stock exchange rules, a subject beyond the scope of this Comment. See generally id. 221-22, 802-04 and corresponding pages in 1969 Supplement.

21. 15 U.S.C. $\$ 89$ to 79z-6 (1976). See ARANOw \& EInHORN 176; Wyser-Pratte 8-9.

22. 15 U.S.C. $\$ 79 \mathrm{k}(1976)$. 
principle was presented by the "merger movement" of the 1960s. ${ }^{23}$ In a merger situation, arbitrageurs focus upon assessing the various risks affecting the likelihood of consummation of the merger. A thorough evaluation of such factors as information regarding the stage of negotiations, possible adverse tax rulings, the likelihood of obtaining the requisite shareholder approval, and potential SEC or antitrust problems enables arbitrageurs to arrive at a price they can afford to pay for the securities of the "bride" while still allowing a margin for profit and absorption of risk. ${ }^{24}$

\section{Tender Offer Arbitrage.}

The rapid increase in tender offers in the past twenty years ${ }^{25}$ has provided the perfect climate for a new and highly profitable application of the arbitrage principle. Professional risk arbitrageurs, consisting almost exclusively of an elite group of Wall Street investment bankers, ${ }^{26}$

23. Wyser-Pratte 9.

24. See id. 11-33 for a general discussion of merger arbitrage. See also text accompanying notes 35-43 infra for a discussion of the factors affecting the price an arbitrageur will pay for target stock in a tender offer, factors which possess many similarities to those at work in a merger situation.

25. See, e.g., ARANow, EINHORN \& BERLSTEIN vi (preface), xvii (introduction) (describing the "torrent" of tender offers since 1972) (approximately 470 tender offers were registered with the SEC between May 1, 1972, and May 1, 1977); Hayes \& Taussig, Tactics of Cash Takeover Bids, HARV. BUS. REV., Mar.-Apr. 1967, at 135 (documenting statistically the rapid proliferation of cash tender offers in the 1960s, id. 136). See generally ARANow \& EINHORN 64-65, 65 n.3; Swanson, S. 510 and the Regulation of Cash Tender Offers: Distinguishing St. George from the Dragon, 5 HARV. J. LEGIS. 431, 432-33 (1968). This increase in tender offers gave rise to passage of the Williams Act, but that Act in no way dampened the incidence of tender offers. On the contrary, such offers have occurred with increasing frequency in the 1970s. See, e.g., Ehrbar, supra note 14, at 83 (referring to "a flurry of 'unfriendly' takeovers that have been enriching arbitrageurs with increasing frequency during the past year or so." The author goes on to explain that "the same low stock prices that have held down the number of conventional mergers and acquisitions have stimulated the unfriendly takeovers. Tender offers, many of which are takeover attempts, have doubled since 1972 to a recent rate of around 100 a year."); Pavly, Wall Street's Tender Trap, NewsweEK, Apr. 11, 1977, at 88 (commenting on tender offers in the mid-70s and observing that "once again the tender offer is becoming a craze," id.); Arbitrage: It's the Hottest Game in Town, supra note 14, at $7 i$ (in 1976 "risk arbitrage grew into what is probably the hottest game on Wall Street. The risk arbitrageurs came up winners on scores of mergers and acquisitions").

26. Traditionally, securities arbitrage in the United States has been engaged in to a significant degree exclusively by a select few Wall Street investment banking firms and arbitrage houses. This is due in part to the degree of complexity involved in a successful arbitrage operation and also in part to the large element of risk and the need for huge amounts of investment capital, factors that discourage the amateur or dilettante investor. Also relevant is the fact that, in many cases, arbitrage activities can be profitably undertaken only if the practitioner has a seat on the New York Stock Exchange (NYSE), a position that facilitates access to the market and yields reduced commission costs. See notes 130-31, 136-37 infra and text accompanying notes 130-37 infra. See generally Ehrbar, supra note 14, at 83. ("professional arbitrageurs . . . are mostly based in a few Wall Street firms-they include Salomon Brothers, Goldman Sachs, Bear Stearns, and L.F. Rothschild"); Rubin, Arbitrage, 32 Bus. LAw. 1315 (1977) ("There are about six or seven 
earn a handsome profit by exploiting the differential between market price and tender price.

Tender offer arbitrage is at its simplest in a cash offer, in which shareholders of a "target" corporation are requested by the "offeror" corporation to tender their shares in return for cash. The arbitrageur estimates his costs, figures in a factor for risk and the desired profit margin, arrives at an estimate of what he can profitably afford to bid, ${ }^{27}$ and then enters the market quickly and quietly, buying large blocks of target stock.

The effect of arbitrageur purchases is to drive up the price of target stock on the market, ${ }^{28}$ thus narrowing the spread between market and tender price. In the event that the spread becomes too narrow, threatening the arbitrageur's profit margin, he will often back off temporarily and liquidate a portion of his position in target stock in order to lower the market price and then will resume purchasing. ${ }^{29}$ As the offer draws to a close, the arbitrageur will pull out of the market, tender his shares and collect his profit. In some cases, where market price is relatively high and the arbitrageur has reason to fear that his tender will be prorated ${ }^{30}$ he will liquidate his position on the market and realize his profits early. ${ }^{31}$

major arbitrageurs new on the Street, and about fifteen firms involved to some extent. All of them are members of the New York Stock Exchange. The large ones, with one exception, act either wholly or primarily for their own account and the total number of people involved in this activity is probably not more than 40." Id. 1315); Arbitrage: It's the Hottest Game in Town, supra note 14, at 71 (arbitrageurs are a "select group of Wall Street plungers" including such longtime specialists as Goldman Sachs, Salomon Bros., Bache, and Sheriff Securities and such notable newcomers as E.F. Hutton, Loeb Rhoades, Prescott, Ball \& Turben, and Merrill Lynch); Wall Street's Highest Rollers, supra note 13, at 54-55 (principal practitioners of arbitrage are wellknown investment houses and "a few individual operators, like Ivan Boesky, a lawyer, accountant, and security analyst." Id. The article characterizes Leonard Sheriff, of Sheriff Securities, as the "dean of the business." Id. 55).

27. For a more detailed discussion of the factors weighed by arbitrageurs in arriving at a purchase price, see notes 35-43 infra and accompanying text.

28. ARANOW \& EINHORN 174. Extensive arbitrageur purchases, like any other large-scale series of purchases of a company's stock, have the effect of raising the market price of that stock. This price increase is compounded by the fact that arbitrageurs generally collect soliciting dealer's fees for shares tendered and experience reduced commission expenses, thus allowing them profitably to bid higher for stock than the average investor. See text accompanying notes 130-37 infra.

29. Henry 471.

30. In order to deal with the inequities engendered by offers which provided for acceptance of only a specified number of shares on a first-come, first-served basis, see note 114 infra and accompanying text, Congress provided in the Williams Act for a 10-day period of time during which tenders made in excess of any maximum contained in the offer must be accepted on a prorata basis. 15 U.S.C. $\$ 78 \mathrm{n}(\mathrm{d})(6)$ (1976).

31. See Henry 471-72. It is to be emphasized that the primary interest of the arbitrageur lies in tendering his acquired position, especially where an exchange offer is involved and the arbitrageur needs to cover short sales of offeror stock. See text accompanying note $49 \mathrm{infra}$. How- 
In most cases, arbitrage pushes the market price toward, but not above, the tender price. ${ }^{32}$ In some cases, however, the market price actually moves above the tender price. ${ }^{33}$ It is not unusual, for example, for arbitrageurs to consider a tender price to be unrealistically low. In such an event, a bidding war often ensues between two or more offerors attempting to gain control of the target corporation; ${ }^{34}$ arbi-

ever, there are some circumstances in which the arbitrageur may wish to sell into the market. One such occasion, alluded to at text accompanying note 29 supra, arises where the arbitrageur sells target stock to increase the spread between market and offer price. Another situation in which it is profitable for the arbitrageur to sell occurs where the market price is near the offer price and it becomes likely that the number of shares tendered will exceed the maximum amount acceptable under the terms of the offer, indicating the probability of substantial proration of tenders. In this event, the current market price for target shares might exceed the average price the arbitrageur would receive if he tendered his shares and later sold any unaccepted shares on a falling market at a loss. It would obviously be wise for the arbitrageur to sell in such a situation.

32. See note 28 supra. It stands to reason that the market price normally approaches the tender price asymptotically. Insofar as the upward price movement is brought about in the first place by the sudden emergence of an opportunity to realize a premium by tendering to the offeror, it should not exceed the value of that opportunity. But see notes 33-34 infra and accompanying text.

33. For example, in 1977 United Technologies Corp. made a $\$ 42$ per share cash offer for the stock of Babcock \& Wilcox Co., a successful corporation operating in the areas of coal and nuclear plant equipment. Soon thereafter, Babcock's stock traded upward from its preoffer price of $\$ 34.75$ per share to above $\$ 42$ per share, reflecting the market's anticipation of a competing offer. J. Ray McDermott, Inc. shortly thereafter made a competing offer, and there ensued a bidding war which ultimately gave McDermott control of Babcock for $\$ 65$ per share. See Tracy, supra note 14, at 266-69; 'Blood in the water' at Babcock \& Wilcox, Bus. WEEK, June 6, 1977, at 25-26; Wall Street's Highest Rollers, supra note 13, at 54. To take another example, in 1976 H.K. Porter Co. made a cash tender offer for the common stock of Fansteel, Inc. at $\$ 17$ per share plus a $\$ .45$ soliciting dealer's fee. Trading in Fansteel, which had been at roughly $\$ 14$ per share, was halted and later reopened at approximately 18-1/2, above the offer price, and soon traded up to 19-1/4. Soon thereafter, a competing offer was made at $\$ 22$ plus a fee, to which Porter successfully responded with an offer of $\$ 23.50$ plus a fee. See Rubin, supra note 26, at 1315-16. See generally Ehrbar, supra note 14, at 84.

34. This was true, for example, in the recent battle between United Technologies Corp. and J. Ray McDermott, Inc. for control of Babcock \& Wilcox Co., and also in the 1976 Porter-Fansteel takeover. See note 33 supra. Another recent situation where a cash tender offer met with competition was MCA's attempted takeover of Coca-Cola Bottling Company of Los Angeles (CCLA). On October 10, 1977, the same day that rumors first began leaking to the public about MCA's proposed offer, CCLA published a letter to its shareholders advising a "wait and see" approach. MCA Will Offer \$140 Million Cash to Buy a Bottler, Wall St. J., Oct. 10, 1977, at 5, col. 2 (discussing proposed MCA tender); Letter to Shareholders from Management of Coca-Cola of L.A., Wall St. J., Oct. 10, 1977, at 19, col. 4. After the precise terms of the offer became known, CCLA recommended that shareholders reject the proposed offer and filed suit against MCA seeking to enjoin the offer. Letter to Shareholders from Management of Coca-Cola of L.A., Wall St. J., Oct. 12, 1977, at 34, col. 4; Bottler of Coke in Los Angeles Fights MCA Bid, Wall St. J., Oct. 12, 1977, at 19 , col. 1 (detailing CCLA's suit against MCA). MCA responded by publishing a formal offer at $\$ 30$ per share for common stock and $\$ 58.50$ per share for preferred stock and by filing a countersuit against CCLA. Offer to Purchase for Cash Any and All Outstanding Shares of Common Stock at $\$ 30.00$ Per Share Net and $\$ 2$ Cumulative Convertible Preferred Stock, Series $A$ at $\$ 58.50$ Per Share Net of Coca-Cola Bottling Company of Los Angeles, Wall St. J., Oct. 13, 1977, at 29-32. Before substantial litigation had occurred, Northwest Industries stepped in as a "friendly" third 
trageurs, anticipating competing tender offers at higher prices, will then push market prices above the original tender price.

\section{The Risks of Tender Offer Arbitrage.}

Arbitrageurs accept risks arising from possible legal impediments to the offer, external economic influences that may upset the offer, ${ }^{35}$ risks arising from the terms and conditions of the offer itself, ${ }^{36}$ and risks traceable to the make-up of the target constituency. Possible legal impediments to the success of a tender offer include the need for approval by a federal or state regulatory agency, ${ }^{37}$ the possible effect of state anti-takeover statutes, ${ }^{38}$ potential antitrust problems ${ }^{39}$ and the likeli-

party and made a competing cash offer which ultimately proved successful. Notice of Offer to Purchase for Cash Common Stock at $\$ 40$ Per Share and Preferred Stock at $\$ 78$ Per Share of CocaCola Bottling Company of Los Angeles by NIW, Inc. a Wholly-Owned Subsidiary of Northwest Industries, Inc., Wall St. J., Oct. 19, 1977, at 34, col. 4.

35. These external economic influences may include, for example, general changes in the economy or governmental money policy, changes in the business or capitalization of either the offeror or the target, or recent adverse earnings reports.

36. Obviously, the terms and conditions of the offer have a great deal to do with its success or failure. Aside from basic price considerations, the arbitrageur must ascertain, for example, whether a minimum tender is required and, if so, whether it is likely to be met. He must also consider the likelihood of proration, whether or not soliciting dealer's fees are available, see note 131 infra and text accompanying notes 131-33 infra, and other similar factors which impact upon the offer's attractiveness.

37. ARANOW \& EINHORN 184. Such a situation is likely to occur where the target is a public utility, common carrier, insurance company, a corporation engaged in the broadcast media, or other similar regulated entity.

38. Many states have enacted anti-takeover statutes in recent years in response to the growing trend of unfriendly tender offers. Such statutes typically impose restrictions and disclosure requirements similar in many respects to the requirements of the Williams Act. However, the state laws tend to be stricter and to impose greater time delays and in many respects are perhaps aimed more at discouraging than at regulating tender offers. See generally ARANOW, EINHORN \& BERLSTEIN 207-57; Langevoort, State Tender-Offer Legislation: Interests, Effects, and Political Competency, 62 CORNell L. Rev. 213 (1977); Shipman, Some Thoughts About the Role of State Takeover Legislation: The Ohio Takeover Act, 21 CASE W. RES. L. REv. 722 (1970); Wilner \& Landy, The Tender Trap: State Takeover Statutes and Their Constitutionality, 45 FordHaM L. REV. 1 (1976). There is serious doubt as to the constitutionality of many of these statutes, and a good argument exists that they are preempted both by the Williams Act and as an undue burden on interstate commerce. See Aranow, EINHORN \& BERLSTEIN 225-33. Indeed, the Court of Appeals for the Fifth Circuit recently so held, affirming a lower court's invalidation of Idaho's anti-takeover statute on both of the above grounds. Great Western United Corp. v. Kidwell, 577 F.2d 1256 (5th Cir. 1978), affg 439 F. Supp. 420 (N.D. Tex. 1977). For the general background of this lawsuit at the district court level, see Takeover Law in Idaho Ruled Unconstitutional, Wall St. J., Sept. 6, 1977, at 4, col. 1.

39. ARANOW \& EINHORN 184. See generally ARANOW, EINHORN \& BerLSTEIN 147-60. Typically, a hostile target management will bring a lawsuit alleging antitrust violations whenever there exists the barest colorable basis for such allegations. It is not essential that target management actually win the case-it is enough that they cause sufficient delay to defeat the offer. See Henry 468. Note, however, the possible breach of fiduciary duty to target shareholders where there is interposed a purely frivolous lawsuit, a subject which is beyond the scope of this Com- 
hood that effective defense tactics will be employed by target management. The arbitrageur must evaluate the merits of litigation instituted by the target management; moreover, even if the target group is ultimately unsuccessful on the merits, delay alone may be sufficient to defeat the offer. ${ }^{40}$

An arbitrageur also must ascertain the number and type of shareholders in the target constituency, their relative holdings and the normal volume of trading in the stock. ${ }^{41}$ The possibility of shareholder loyalty ${ }^{42}$ to target management must be considered, and estimates must be made of the number of shares held by "friends" of target management, who may have agreed not to tender. An arbitrageur prefers a corporation in which large blocks of stock reside with institutional investors, since institutional shareholders are the most likely to cash in to avoid the risks of the offer. ${ }^{43}$

ment. A recent example of a situation where an antitrust suit succeeded in defeating a tender offer is presented by Anderson, Clayton \& Co.'s attempted takeover of Gerber. There, Gerber responded with an antitrust suit, which it succeeded in having split for separate, consecutive trials on two issues, a procedural device which would have insured years of delay. Not surprisingly, Anderson, Clayton withdrew its offer. See Bid by Anderson Clayton to Buy Gerber Dropped, Wall St. J., Sept. 20, 1977, at 48, col. 1.

40. See note 39 supra.

41. The arbitrageur normally attempts to isolate target stock according to the class of shareholder by which it is held, i.e., target insiders, institutional investors, the offeror, other arbitrageurs and the public. He then evaluates the likelihood of tenders from each class. ARANOw \& EINHORN 187; Wyser-Pratte 58-59.

42. Although some commentators argue that there is no such creature as a "loyal shareholder," see, e.g., O'Boyle, Changing Tactics in Tender Offers, 25 Bus. LAw. 863, 866 (1970), at least some shareholders may be so characterized. Three potential classes of "loyal shareholders" come to mind. First, management personnel and other employees of the target corporation often own significant amounts of target stock, frequently pursuant to employee stock purchase plans. The probable affinity of such shareholders for incumbent management is obvious. Second, there are often many small "Mom and Pop"-type shareholders who have held their shares for many years and are pleased with the policies of incumbent management. Such shareholders are the most likely candidates to be swayed by management's exhortations that the offeror is nothing more than a "corporate pirate" or "raider" intent on looting the target corporation and may well choose not to tender even when tendering would be in their financial best interest. This is especially true where the target corporation is an established local or regional operation and the offeror is viewed as an "outsider." A third type of "loyal shareholder" is the large investor, typically an institution, whose investment in the target goes well beyond common stock and may include substantial holdings of preferred stock, bonds, debentures and other substantial long-term financing commitments. Often such an investor will be represented on the target's board of directors. Presumably, where such an investor enjoys a cozy and mutually beneficial relationship with incumbent management, it will be unwilling to upset the applecart by tendering. However, the other side of the coin is that such a shareholder may be forced to tender or sell on the market in order to avoid charges that it has breached a fiduciary duty to its own shareholders to obtain the premium proffered by the offeror. See notes 43,119 infra and accompanying text.

43. The institutional investor who merely holds blocks of the target's common stock as a 
Finally, the arbitrageur must consider a number of additional factors-the possibility of proration; the costs of capital, specialist fees and transfer taxes; the availability of soliciting dealer's fees; and his own desired profit margin-to arrive in the end at the price he is willing to pay for tendered shares.

In the case of exchange offers, this process becomes even more complex. Arbitrageurs tend to view exchange offers as more risky undertakings than tender offers ${ }^{44}$ for a variety of reasons, including the need for registration of the offeror's new issue of securities, increased SEC scrutiny ${ }^{45}$ and the possible need for approval by the offeror (issuer) shareholders. ${ }^{46}$ These requirements usually lengthen the period of the offer and totally eliminate the element of surprise, thus providing target management with more time to react and to engage in defensive tactics. ${ }^{47}$ In addition, many target shareholders do not wish to become investors in the offeror corporation or may be confused as to parity where a complicated package is offered. Thus, where they would arguably accept a cash offer, some might react negatively to an exchange offer. ${ }^{48}$

The mechanics of exchange offer arbitrage are slightly more complicated than those of a cash offer. The arbitrageur figures parity, risk, costs, profit and price as in the case of a cash offer. However, he must also sell short the securities offered in the deal. He then exchanges his

liquid investment is unlikely to have any particular loyalties and is simply out to get maximum earnings on its investment. At the same time, such an investor is under fiduciary obligations to its own shareholders and, thus, would prefer to steer clear of risky undertakings which might engender shareholder discontent and result in litigation. The option of selling onto the market at a premium, with no risk whatsoever, is particularly appealing to such an investor. The institutional investor may also prefer to sell on the market rather than tender for tax reasons discussed at note 119 infra. In some cases, however, a conflict is created for the institutional investor whose investment in the target is substantial, extending beyond mere ownership of common stock and who therefore would prefer not to sell but nevertheless feels pressured to do so. See note 42 supra. For a more thorough discussion of the role of the institutional investor in the tender offer process, see note 119 infra and text accompanying notes 117-19 infra.

44. One commentator notes that, although arbitrageurs exhibit a notable preference for cash offers, exchange offers would appear to have better chances of success. Henry 469 n.20. A study of tender offers from 1956 to 1967 found that exchange offers were twice as likely to succeed as were cash offers. See Austin \& Fishman, The Tender Take Over, MERgers \& ACQuisitions, May-June 1969, at 13-14.

45. Henry 469.

46. For example, shareholder approval is required if the offeror needs to authorize the issuance of new shares with which to consummate the exchange transaction.

47. Henry 469.

48. This can work both ways, however. Since the arbitrageur is offering cash on the market for the target company's stock, he often aids in placing the offeror's issue by creating a cash alternative for those who would not otherwise tender. See notes 60-61 infra and accompanying text. 
acquired position in target stock and covers his short position in offeror stock. In the event the offer fails, the arbitrageur faces the added risk that, in addition to having to dump target shares in the market, he may also have trouble covering his short position in offeror stock on the market without driving the price up and incurring additional losses. ${ }^{49}$

A final consideration distinguishing exchange offer arbitrage from the cash offer variety focuses upon the care an exchange offer arbitrageur must exercise not to run afoul of section 5(a) of the 1933 Securities Act, ${ }^{50}$ which prohibits the sale of new issues of securities prior to the effective date of their registration statement. ${ }^{51}$ It is perfectly legitimate for the arbitrageur to begin selling short the offeror's securities prior to the effective date of the registration statement so long as there are existing registered securities of the same class outstanding; however, he violates section 5(a) if he later covers his short position with securities received in the exchange, which are of the new issue, since he is then "selling" the new securities prior to the effective date of the registration statement. ${ }^{52}$ To surmount this obstacle the arbitrageur must act quickly to cover his short position as soon as the registration statement becomes effective, and presumably before the new shares have hit the market, thus covering with "old" shares. The arbitrageur then almost immediately reestablishes his short position in offeror stock, remaining at the mercy of the market for only a brief period of time. When this new short position is covered with" "new" securities, no problem arises since it was acquired after registration had become effective. ${ }^{53}$

49. ARANOW \& EINHORN $180-81$.

50. 15 U.S.C. $§ 77 \mathrm{e}(\mathrm{a})$ (1976).

51. Id. This is the so-called "gun-jumping" provision of the 1933 Act. Section 5(a) specifically prohibits the "direct or indirect" sale or carriage for the purpose of sale of an unregistered security where there is "use of any means or instruments of transportation or communication in interstate commerce or of the mails."

52. Henry 474-75. Note, however, that since Henry's article appeared, the SEC has created a limited exception to this general rule by agreeing not to recommend enforcement actions for violation of section 5(a) where the arbitrageur meets certain specified conditions. See No-Action Letters from SEC to Messrs. Cleary, Gottlieb, Steen \& Hamilton, dated Jan. 12, 1973 (available Feb. 11, 1973), and Feb. 16, 1973 (available Mar. 18, 1973) (collectively referred to by the SEC in later no-action letters as the "arbitrage letters"). Observe, however, that the conditions for exemption of arbitrageurs are rather strict and include provisions to the effect that the arbitrageur will not acquire more than 10 percent of the securities covered by the exchange offer registration statement and that he will not sign a soliciting dealer's agreement or collect any soliciting dealer's fees. This latter requirement is particularly troublesome to the arbitrageur, insofar as most offers do in fact provide for a soliciting dealer's fee, and in many cases the arbitrageur would not make a profit without the fee. See notes 131, 137 infra and text accompanying notes 131-33.

53. Henry 474-75. 


\section{Traditionally AdVanced Justifications for the Nonregulation of Tender OfFer Arbitrage}

The existence of an outstanding tender offer creates a variety of pressures upon target shareholders. They must weigh the merits of the offer, its chances for success, the value of their holdings as a continuing investment, the price a sale would bring on the market and other like considerations. Such an undertaking often calls for a degree of financial acumen beyond that possessed by the average unsophisticated investor.

It is a commonly held view that since arbitrageurs are better able to assess these risks and contingencies than is the average shareholder, and are willing to shoulder the risks in return for the possibility of a large profit, they should be freely permitted to do so. ${ }^{54}$ The arbitrageur provides the investor with a riskless alternative to tendering or holding onto his shares, giving the shareholder the option of selling his stock at a gain on the market and reinvesting his money elsewhere. From that point onward, the arbitrageur assumes the risk of litigation, delay, failure of the offer, proration and the like. ${ }^{55}$

The existence of an option to sell on the market into the hands of arbitrageurs protects target shareholders against proration in the event more shares are tendered than will be accepted under the terms of the offer. Were the target shareholders forced to unload these unaccepted shares on a falling market, they would most likely suffer substantial losses. $^{56}$ The arbitrageur is in a better position to minimize these losses by virtue of his ability to enter the market quickly and on better terms than the average investor. ${ }^{57}$

The target shareholder is also protected against the possibility that, should he retain his stock, it will ultimately be delisted or absorbed by some form of minority shareholder "freeze-out" such as a short-form merger. ${ }^{58}$ By creating a market for target stock, the arbitrageur gives

54. See, e.g., ARANOW \& EINHORN 174; Henry 483.

55. These risks are, of course, reflected in the price the arbitrageur is willing to pay for target stock. See notes 35-43 supra and accompanying text.

56. The market for target shares normally falls substantially following a tender offer, due in large part to "dumping" of unaccepted shares on the market. For example, in the Anderson, Clayton-Gerber offer discussed at note 39 supra, Gerber was selling at $\$ 33$ per share prior to Anderson, Clayton's $\$ 40$ offer. Gerber's price quickly rose to more than $\$ 39$ following announcement of the offer. When the offer fell through, so did the price-to levels below $\$ 28$ per share.

57. Because the arbitrageur normally is a NYSE member, he possesses a double advantage over the average investor: first, he can get to the floor of the exchange more quickly to unload his shares and, second, he avoids all but floor brokerage expenses. See note 130 infra and accompanying text.

58. Many states have corporate law provisions which allow a corporation with large holdings in a subsidiary (e.g., $90 \%$ or greater) to undertake a "short-form" merger of the subsidiary into the 
target shareholders the opportunity to avoid the risks of being left holding stock whose value is down on the market, and which may shortly become unmarketable and lose its character as a liquid investment.

Even sophisticated investors are arguably benefitted by arbitrageur participation in a tender offer. Insofar as their sophistication equips them with an awareness of the normal signs of arbitrageur activity, such knowledge serves as a signal to them of the consensus among the arbitrage community as to whether or not the offer will succeed, and hence is an aid in their own decision-making process. ${ }^{59}$

Where an exchange offer is involved, the arbitrageur makes a market for the target stock and thus insures a cash alternative for target shareholders who do not wish to own stock in the offeror corporation. ${ }^{60}$ Exchange offer arbitrage further helps to insure the success of the offer by, in effect, placing the issue of the offeror in the hands of those who purchase when the arbitrageur sells short. ${ }^{61}$ This arguably is of critical

parent, without the need for approval of other minority shareholders in the subsidiary. See, e.g., DEL. CODE tit. 8, \& 253 (1974). Although many such jurisdictions also provide rights of dissent and appraisal for discontented minority shareholders, see, e.g., DeL. CoDE tit. 8, § 262 (1974), it is questionable whether such rights are really meaningful, since the shareholder generally does not get a price any better than that which he could have obtained on the market, and in addition he must wait longer to receive that price and often incurs litigation expenses. See generally Manning, The Shareholder's Appraisal Remedy: An Essay for Frank Coker, 72 YALE L.J. 223 (1962). Thus, if an offeror acquires large holdings in the target (which thus becomes a subsidiary of the offeror), the minority shareholder faces the possibility of holding unmarketable stock worth significantly less than before the takeover. For a general discussion of the problems associated with minority shareholder "freeze-outs" and related "going private" transactions, see J. FLOM, M. Lipton \& E. Steinberger, TAkeovers and Takeouts-Tender Offers and Going Private (1976).

59. See Henry 470.

60. In many cases, the target shareholders have no interest in receiving the offeror's securities. This may simply be a consequence of the fact that they feel the offeror corporation is not a good investment. There may also be a reluctance to tender on the part of target shareholders where the package put forth by the offeror would replace equity securities with debt instruments. See O'Boyle, supra note 42, at 865; Rubin, supra note 26, at 1317. In these situations arbitrage creates a demand for target shares and insures a cash alternative to the receipt of offeror securities.

61. An interesting peripheral question is who buys the offeror securities when the arbitrageur sells them short. One plausible answer was proposed by O'Boyle, who postulates what might be described as a "second level" of arbitrage. See O'Boyle, supra note 42, at 867-68. The theory, briefly stated, is that "friends" of the offeror manage to get wind of the proposed exchange offer early. Since the price of an offeror's stock usually rises slightly just prior to the offer's formal announcement, based on rumors which inevitably leak out concerning the offer, these "friends" will take advantage of the public leaks by having earlier accumulated a position in offeror stock which they proceed to sell, as well as assuming a short position in offeror stock, immediately prior to announcement of the offer. The price of offeror stock will then typically fall after the offer is announced. It is at this point that arbitrageurs are selling short offeror stock, and O'Boyle theorizes that the "friends" purchase this stock from the aribtrageurs in order to cover their own preexisting short positions, thus consummating the "second level" of arbitrage. Id. 
importance to many exchange offers, which might otherwise fail for lack of target shareholders willing to accept offeror stock.

One interpretation of the above observations is that arbitrage helps to facilitate the smooth operation of the tender offer process by creating markets for target and offeror stock and helps to insure the orderly transition of market prices by gradually eliminating the spread between market and tender price. ${ }^{62}$ Some commentators argue that this process would occur even in the absence of arbitrage, but that arbitrage helps it to happen in a faster, smoother, more efficient manner. ${ }^{63}$

Finally, proponents of arbitrage argue that the activities of arbitrageurs are in accord with what is assumed to be the basic policy of the federal securities laws-investor protection. According to this view, target shareholders can never be hurt by arbitrage because they are under no compulsion to sell; if they do choose to sell, they are actually helped because they are given a cash alternative to the tender process at a price in excess of what they would receive on the market in the absence of arbitrage.

If these views are accepted, arbitrage must be considered a healthy force in the marketplace and ought to be allowed to flourish unabated. This characterization of arbitrage is consonant with the maxim that in a free enterprise system those who bear the risks deserve to reap the rewards. Under this view the ever-present risk of failure is sufficient to keep arbitrage in check. As aptly stated by one observer:

An arbitrageur is one who. . . stands between the two parties in transactions involving equivalents and guesses how the opinions that each man has of what the other man wants will vary. If he guesses right, he can make a great deal of money. If he guesses wrong, he doesn't stay in the arbitrage business very long . . . .64

\section{The Case for Regulation of Tender Offer Arbitrage}

The preceding analysis, while superficially appealing, nevertheless fails to deal adequately with the real problem brought about by tender offer arbitrage - an imbalance of existing tender offer regulation giving rise to the potential for long-term damage to the economy. It may well

62. See generally Henry 471-74, 483; see also Evans $63-74$ (discussing in general the problems of supply and demand associated with various types of risk arbitrage).

63. See, e.g., Rubin, supra note 26, at 1316-17. Arguably, however, what happens with the help of arbitrage would not always inevitably occur absent its influence, insofar as the mere presence of arbitrage in many cases affects the chances for success of the offer. This observation is central to the argument developed in Part III of this Comment infra and is examined at length therein.

64. Bedingfield, Personality: A Banker for the Murchisons, N.Y. Times, June 4, 1961, $\S 3$, at 3 , col. 3. 
be that actions taken thus far to regulate the target and offeror are largely ineffectual in achieving a fair balance in the absence of regulation of the third essential party in the tender offer process-the arbitrageur. Arguably, Congress has thus far addressed only the tip of the iceberg.

Under normal circumstances, the securities market is "efficient," that is, it reflects all available information in stock prices, so that no individual investor can enjoy disproportionate gains over any sustained period of time by virtue of his knowledge or position. ${ }^{65}$ The announcement of a tender offer complicates the process, but the market should nonetheless continue to behave efficiently, absent the interference of arbitrage. ${ }^{66}$ Arbitrageurs, however, are able to short-circuit the process and to sustain profits beyond the reach of the general investing public.

The consequences of this departure from efficiency are significant. The delicate balance of tender offer regulation is shifted in favor of the offeror because of the tremendous pressure exerted upon investors to sell target stock which will ultimately end up in the hands of arbitrageurs. ${ }^{67}$ The phenomenon is accelerated as more and more stock falls into the hands of arbitrageurs, decreasing the risk that the offer will fail and, hence, increasing pressure on investors to sell by permitting arbitrageurs to raise the price they are willing to pay.

The beneficiaries of this phenomenon are the target shareholders and the arbitrageurs, both of whom receive windfall profits. These windfalls are not justified by the goals of investor protection. ${ }^{68}$ Arbitrageurs cannot rightfully seek refuge in the concept of free enterprise since they violate one of its first premises-that investors have access to the market on equal terms. ${ }^{69}$ Arbitrageurs exploit a near-monopolistic position, upsetting the market's ideal balance. To better understand what that ideal should be, it is necessary to discuss in some detail the economic theory that best explains market behavior and upon which market regulation should be grounded.

65. The theory of efficient capital markets is discussed at text accompanying notes 71-104 infra.

66. See text accompanying note 105 infra.

67. The effects of market inefficiency upon the balance of tender offer regulation, and upon the economy as a whole, are discussed at sections $C$ and $D$ of this Comment. See text accompanying notes $110-26$ infra.

68. See text accompanying notes 127-29 infra.

69. See notes 130-31, 136-37 infra and text accompanying notes 130-37 infra for a detailed discussion of the special advantages arbitrageurs have vis-à-vis the ordinary investor. 


\section{A. The Efficient Capital Market Hypothesis-A Theoretical Digression. ${ }^{70}$}

The term Efficient Capital Market Hypothesis (ECMH) denotes the most recent advance in a line of theoretical and empirical economic research that has achieved growing acceptance in the past two decades. The ECMH theory had its origin in the observation that successive price movements of individual stocks or groups of stocks are apparently patternless in character. ${ }^{71}$ Application of mathematical and statistical aids to historical market information confirmed the absence of a pattern in stock price changes and prompted the conclusion that such changes are essentially "random."72 This came to be known as the "random walk" theory of stock prices. ${ }^{73}$

Subsequent attempts to explain theoretically the observed randomness of stock price changes led to the development of the ECMH. Simply stated, the ECMH postulates that stock markets are "efficient"-that they fully reflect all available information through efficient information processing and that any future price movement will be the result of entirely "new" information. According to the ECMH, this new information, by definition incapable of advance prediction, will have a random impact upon changes in stock prices. ${ }^{74}$

The ECMH is naturally controversial in the investment community because it implies that under efficient market conditions no investor using only information generally available to other investors can

70. The author wishes to acknowledge at the outset that the organization of the following section of this Comment is based upon Stanford Note and Fama, Efficient Capital Markets: A Review of the Theory and Empirical Work, 25 J. FINANCE 383 (1970), both of which provide an excellent overview of the theory and research comprising the Efficient Capital Market Hypothesis.

71. The earliest documentation of randomness in security price changes was based upon observations of price patterns in the French commodities market. See L. BACHELIER, THEORIE DE La Speculation (1900), translated into English in The Random Character of Stock Market Prices 17 (P. Cootner ed., rev. ed. 1964). It was not until 1959, however, that modern work began to appear which utilized mathematical and statistical methodology aimed at proving stock price change randomness. See Osborne, Brownian Motion in the Stock Market, 7 OperaTrons RESEARCH 145 (1959); Roberts, Stock-Market "Patterns" and Financial Analysis: Methodological Suggestions, 14 J. FINANCE 1 (1959). This work, and its theoretical significance, is discussed in more detail at notes 85-87 infra and accompanying text and in authorities cited therein.

72. See note 71 supra, notes $85-87$ infra and accompanying text. See generally LORIE \& HAMILTON 71-82; Stanford Note 1040-44.

73. The term "random walk" has been a part of the statistician's vocabulary for over seventy years and was, as far as can be determined, first coined in an exchange of correspondence between Karl Pearson and the Right Honorable Lord Rayleigh appearing in NATURE in 1905. 72 NatURE $294,318,342$ (1905). See LORIE \& HAMILTON 71. The term originated as descriptive of the path taken by a disoriented person left to wander aimlessly in an open space. It has since proven adaptable to data depicting stock price movements.

74. See generally LORIE \& HAMILTON 79-82, 97; Stanford Note 1035-41. 
systematically identify securities that are undervalued or overvalued, ${ }^{75}$ ostensibly rendering research into stock pricing models futile. To support the ECMH, three factors implicit in the theory must be empirically verified: "the determinants of security values, the processes of security price formation and the characteristics of prices that 'fully reflect' available information."76 To this end, theorists have attempted first to isolate the variables which investors weigh, consciously or unconsciously, in determining the price they are willing to pay for a security and, second, to formulate mathematical models or equations which accurately portray the interrelationship of these variables as they interact to determine security prices. By resorting to such models, theorists may verify the validity of the ECMH by comparing the expected behavior of the market under the ECMH with actual observed behavior.

To develop a theory of security valuation, certain basic assumptions must be made about investor behavior. The common approach of economists is to assume that investors want to make as much money as possible with as little risk as possible. Thus, the value of a security is a function of its "expected returns,"77 discounted by a factor for "risk" which represents the degree of uncertainty in the determination of expected returns. These assumptions have led to the development of

75. Stanford Note 1035. A security is "undervalued" when available information would indicate that the security should be selling at a higher price. Similarly, a security is "overvalued" when available information dictates a lower price for the security than that which prevails in the market. The "intrinsic" value of a security is the theoretical value that the security would have if all information which could be known about it were reflected in its price. In an efficient market, it is possible for there to exist stocks priced other than at "intrinsic" value. The catch, however, is that no investor is able to identify such stocks. Stated alternatively, there is no stock that is overvalued or undervalued in the sense that there is available information about the stock that would indicate a price other than that which prevails; the existence of information not already reflected in the stock's price would contradict the premise of market efficiency that stock prices reflect all available information. Id. n.23.

76. Stanford Note 1036, see Fama, supra note 70, at 384. See also B. Lev, Financial Statement ANalysis: A New Approach 217-18 (1974).

77. It is a basic economic principle that the value of an asset lies in the income it can produce for its owner. Stated in financial terms, the value of an asset is the present value of future cash flows that it can provide to its owner. These cash flows derive from two sources: first, periodic payments with respect to the asset such as dividends and interest and, second, the price realized upon disposition of the asset. See, e.g., LORIE \& HaMiLTon 113-14.

The "expected returns" or "expected value" of an investment asset is a weighted value that attempts to account for all contingencies and to ascertain a statistically "most likely" value. It represents "the sum, over all possible events, of the probability of an event times its value" should it occur. Stanford Note 1036 n.25.

78. "Risk" is nothing more than uncertainty as to the outcome of future events. It is a basic principle of economics, as well as common sense, that investors seek to avoid risk and will demand greater returns on their capital as risk increases. For general discussions of investor behavior with regard to incurring risk see, e.g., Friedman \& Savage, The Expected-Utility Hypothesis and the Measurability of Utility, 60 J. POL. Econ. 463 (1952); Tobin, Liquidity Preference as Behavior Towards Risk, 25 REv. ECON. STUD. 65 (1958). 
portfolio theory, ${ }^{79}$ which, in combination with other economic theory, ${ }^{80}$ seeks to explain price determination in capital markets.

When these price determination theories are assumed to apply in an efficient market, it follows that all available information is a factor in determining expected returns and risk, and, hence, all available in-

79. Portfolio theory was developed by economists as an attempt to explain the behavior of rational investors in choosing investments. Since a detailed discussion of portfolio theory is beyond the scope of this Comment, this author will briefly track the conclusions that have been reached by theorists insofar as they are relevant to the present inquiry and will cite the reader elsewhere for detailed exposition. For a good general and nontechnical discussion of the subject see LORIE \& HAMILTON.

Before developing any theory of investor behavior, theorists had to arrive at a statistical measure for risk. The measure most often chosen has been the standard deviation, which in this case is used to measure variation in the probability distribution of expected returns on a security. A large standard deviation corresponds to higher risk and hence causes investors to demand greater returns. See H. Markowitz, Portfolio Selection: Efficient Diversification of Investmenrs (1959); Markowitz, Portfolio Selection, 7 J. Finance 77 (1952). The corollary of this proposition is that, among assets having the same expected returns, investors prefer those with smaller standard deviations and, among assets with the same standard deviations, investors seek the greatest expected returns. See, e.g., W. Sharpe, Portfolio Theory and Capital Markets 26-27 (1970).

Portfolio theory has demonstrated that the risks inherent in holding any particular stock can be greatly reduced through a process known as "diversification," whereby the investor scientifically acquires stock in a variety of enterprises, in effect approximating the behavior of the market as a whole. See H. MARKowITz, supra. It is mathematically possible to determine the precise behavior of a portfolio of securities based upon the interrelationship, or correlation, of each pair of securities within the portfolio. W. SHARPE, supra, at 117-19. Such a computation is normally complex and impractical (even for a computer); therefore, most stock analysts use simplified models, based upon the relationship of each individual stock to a common index, such as the Dow Jones Average. Id. 119-40. It can be mathematically demonstrated that, through proper diversification, variability related only to the specific securities chosen can be eliminated. See, e.g., E. Fama \& M. Miller, The Theory of Finance 253-55 (1972).

80. The results of portfolio theory have been used to develop a model that explains how capital asset prices are determined. This model has come to be known as the Capital Asset Pricing Model (CAPM). See Lintner, The Valuation of Risk Assets and the Selection of Risky Investments in Stock Portfolios and Capital Budgets, 47 Rev. ECON. \& STATISTICs 13 (1965); Sharpe, Capital Asset Prices: A Theory of Capital Market Equilibrium Under Conditions of Risk, 19 J. FINANCE 425 (1964).

Nearly all empirical tests of the ECMH, see text accompanying notes 84-101 infra, have used some form of expected return analysis as a starting point. The CAPM has been especially useful in this regard. Thus, although the ECMH itself is independent of the validity of the CAPM, many of the empirical tests of the ECMH do depend on this model's reliability. Research to date indicates that the CAPM is reasonably accurate. See, e.g., Douglas, Risk in the Equity Markets: An Empirical Appraisal of Market Efficiency, 9 YALE ECON. EssAYs 3 (1969); Fama \& MacBeth, Risk, Return and Equilibrium: Empirical Tests, 81 J. PoL. ECON. 607 (1973); Miller \& Scholes, Rates of Return and Relation to Risk, A Re-examination of Some Recent Findings, in STUDIES IN THE THEORY OF Capital Markets (M. Jensen ed. 1972); cf. Blume \& Friend, A New Look at the Capital Asset Pricing Model, 28 J. FINANCE 19 (1973) (suggesting inconsistencies in the model's results). Even if the CAPM were found to be deficient, the ECMH would not necessarily be refuted, for such a finding could mean only that standard deviation is an inadequate measure of risk or that investors employ criteria in addition to expected returns when assessing available information regarding an investment asset. Stanford Note 1038 n.30. 
formation is reflected in stock prices. ${ }^{81}$ Under such a theory, no investor can systematically identify mispriced stock. ${ }^{82}$ As a corollary proposition, securities prices are such that the expected rate of return is equal for all securities having the same degree of risk. ${ }^{83}$

Research supporting the validity of the ECMH is of three basic varieties, corresponding to the types of information under consideration. ${ }^{84}$ The "weak form" verification of the ECMH tests whether information about past price changes is reflected in current prices. The "semistrong form" measures the rapidity with which stock prices adjust to currently available information. The "strong form" applies semistrong tests to measure market adjustment to nonpublic information.

The weak form of the ECMH asserts that all information which can be derived from past price changes is incorporated into present security prices. Attempts to test this assertion have adopted two different approaches. One line of inquiry examines actual sequences of security price movements for statistical properties indicating randomness. ${ }^{85}$ The other approach involves an attempt to disprove the weak form hy-

81. The theory of the Capital Asset Pricing Model can be used to derive equations that, when taken together, mathematically demonstrate the impossibility, except by pure chance, of an investor's generating above average returns, assuming that securities are priced according to expected returns. Stanford Note 1038-39 n.31. See E. FAMA \& M. Miller, supra note 79, at 335-38.

82. Stanford Note 1038-39. See note 75 supra and accompanying text.

83. Stanford Note 1039. See note 79 supra.

84. See Lorie \& Hamilton 71; Stanford Note 1041.

85. As indicated at note 71 supra, observers noted the apparent randomness of securities price movements as early as 1900 . It was not until the late 1950 s and the 1960 s, however, that such observations were subjected to exacting mathematical and statistical analysis. For example, Roberts indicated in a 1959 study that series of numbers created by cumulating random numbers displayed the same visual appearance as a time series of stock prices. Roberts, supra note 71, at 4-6. Osborne, a well-known physicist, undertook a unique study of security price changes which compared such changes to the movement of small particles suspended in solution-known as "Brownian motion"-and observed a high degree of correlation between price movements and the laws of physics governing Brownian motion. Osborne, supra note 71, at 145.

There followed in the 1960s a series of tests, utilizing various statistical methods of analyzing time series of stock prices, which uniformly were able to discover, at most, insignificant departures from randomness, thus lending strong support to the weak-form ECMH. See, e.g., Fama, The Behavior of Stock Market Prices, 38 J. Bus. 34 (1965); Granger \& Morgenstern, Spectral Analysis of New York Stock Market Prices, 16 KykLos 1 (1963); Moore, Some Characteristics of Changes in Common Slock Prices in The Random Character of Stock Market Prices 139-61 (P. Cootner ed. 1964).

In 1965, Professor Samuelson first published a rigorous mathematical proof that prices necessarily move randomly in an efficient market. Samuelson, Proof that Properly Anticipated Prices Fluctuate Randomly, 6 INDUs. MANAGEMENT REv., Spring 1965, at 41. Implicit but unstated in Samuelson's proof are the following conditions for market efficiency: (1) absence of transaction costs to investors; (2) absence of information costs to investors; and (3) homogeneous expectations among investors regarding the returns on securities when given equal access to information. See Stanford Note 1040 n.38. However, it is not always necessary for these "ideal" conditions to exist for the market to approximate efficiency. See text accompanying note 103 infra. 
pothesis by devising profitable trading schemes based upon past patterns of price movements. ${ }^{86}$ Both methods of testing the weak form hypothesis have produced consistent and convincing empirical evidence that present price movements are unaffected by information derived from past trends. ${ }^{87}$

The semistrong form of the ECMH asserts that prices react rapidly and without bias to information as it is made publicly available. Empirical tests of this hypothesis have focused upon measuring the speed of adjustment and upon determining the type of information to which prices react. ${ }^{88}$ Tests designed to measure speed of adjustment most often compare the performance of a particular security with that of the market as a whole during the particular period of time encompassing the public release of information pertaining to the security. ${ }^{89} \mathrm{Re}-$ searchers look for significant deviations of the security's price from its "normal" relationship with other market prices as indications of adjustment to the new information. ${ }^{90}$ Tests of this nature have been applied to the public announcement of stock splits, annual earnings reports and secondary offerings of common stock, as well as to a variety of other types of information made public by filing with the SEC, publication by the financial press or other similar means. ${ }^{91}$ In virtually every case, "the empirical evidence indicates that security prices react extremely rapidly." "92 Often, such adjustment begins to occur well before the for-

86. See Alexander, Price Movements in Speculative Markets: Trends or Random Walks, 2 Indus. Management Rev., May 1961, at 7; Alexander, Price Movements in Speculative Markets: Trends or Random Walks, No. 2, 5 Indus. MaNAGEMENT REv., Spring 1964, at 25. Although Alexander's first efforts to disprove the weak-form ECMH by devising profitable trading schemes appeared to be successful, it has since been shown that, in practice, transaction costs (which Alexander ignored) and other related market imperfections consume any minor advantage that might otherwise adhere in such trading schemes. See Fama, supra note 85; Fama \& Blume, Filter Rules and Stock Market Trading, 39 J. Bus. 226 (1966). See generally Cootner, Stock Prices: Random versus Systematic Changes, 3 Indus. Management Rev., Spring 1962, at 24; Van Horne \& Parker, Technical Trading Rules: A Comment, Financial ANALysts J., July-Aug. 1968, at 128.

87. See generally LORIE \& HAMILTON 71-82; Stanford Note 1041-44. See also authorities cited at notes $85-86$ supra.

88. Stanford Note 1044. See generally LORIE \& HAMILTON 83-87.

89. Stanford Note 1044.

90. Id.

91. See, e.g., Ball \& Brown, An Empirical Evaluation of Accounting Income Numbers, $6 \mathrm{~J}$. ACCOUNTING RESEARCH 159 (1968) (analyzing the impact of corporate annual earnings reports on stock prices and concluding that the market begins to react even prior to the formal announcement of earnings); Fama, Fisher, Jensen \& Roll, The Adjustment of Stock Prices to New Information, 10 INT'L ECON. REV. 1 (1969) (examining the effect on the market of stock splits by NYSE-listed stocks during 1927-1959); Scholes, The Market for Securities: Substitution versus Price Pressure and the Effects of Information on Share Prices, 45 J. Bus. 179 (1972) (examining the effect upon stock prices of secondary offerings of common stock).

92. Stanford Note 1044. 
mal announcement of the information. ${ }^{93}$

A second type of semistrong test is directed towards ascertaining the types of currently available information to which the market will respond. Specifically, such a test measures the market's reaction to information that, although not formally publicized, can be derived from information that is freely available. Assuming the validity of the semistrong form assertion that the market absorbs all publicly available information, the market will not respond to the announcement of information that was already deducible from previously released information. ${ }^{94}$ Nor will the market respond to financial information which is solely the result of cosmetic changes in accounting methods or to other similar information that does not alter the underlying economic worth of the security. ${ }^{95}$

These propositions have been borne out by studies which have examined the effect upon stock prices of various accounting changes. ${ }^{96}$ Overwhelmingly, these studies indicate that resultant changes in stock prices reflect only the actual economic significance of the accounting changes, such as altered tax consequences, and do not merely reflect the cosmetic changes in the reported figures. ${ }^{97}$ Such empirical results pro-

93. See, id. 1046 and authorities cited at $\mathbf{n . 7 7}$ therein. Such pre-announcement adjustments are consistent with efficient capital market theory, insofar as they support the inference that the market reacts speedily to all available information, including the leaks which inevitably precede formal announcements.

94. In other words, the market is presumed to know something as soon as it becomes knowable, without the necessity of a formal public announcement.

95. See Stanford Note 1048.

96. See Kaplan \& Roll, Investor Evaluation of Accounting Information: Some Empirical Evidence, 45 J. Bus. 225 (1972) (studying the effect upon stock price of a change in investment tax credit reporting from deferral to flow-through and in depreciation from accelerated to straight line method); Sunder, Relationship Between Accounting Changes and Stock Prices: Problems of Mea. surement and Some Empirical Evidence, 11 J. AcCounTING RESEARCH 1 (Supp. 1973) (examining stock prices changes following inventory accounting method changes from first in, first out (FIFO) to last in, first out (LIFO), or vice versa); Sunder, Stock Price and Risk Related to Accounting Changes in Inventory Valuation, 50 Accounting Rev. 305, 314 (1975) (also dealing with inventory accounting changes).

97. Stanford Note 1047-50. Consider, for example, Sunder's study of inventory accounting changes. Normally, a switch from FIFO to LIFO will result in a decrease in reported earnings (assuming that the cost of inventory is rising), insofar as the change will increase the cost of goods sold by utilizing higher priced inventory first. However, this accounting change has no real effect on the underlying cost of the inventory. The change may, however, produce real economic benefit in the form of tax deferrals, since the recognition of income has been deferred. If the market responds to cosmetic accounting changes, it would tend to fall when reported earnings per share fall; if, however, it responds only to underlying economic realities, the market price should increase to reflect the monetary benefits of a tax deferral. Sunder's study found that the market responded in the latter fashion, thus reinforcing the semi-strong ECMH assertion that the market responds rapidly to real economic changes while ignoring merely cosmetic changes or redundant announcements of information already available and reflected in existing prices. See Sunder, 
vide additional support for the ECMH in its semistrong form.

The strong form of the ECMH asserts that even nonpublic information is reflected rapidly in security prices. This is not to assert that investors who have access to such information cannot exploit it so as to earn disproportionate returns; rather, the strong form hypothesizes that few investors have access to such nonpublic information not already reflected in securities prices. Even where such access exists, it is usually for brief periods only, since the information begins to go public the moment it is traded upon, so that no individual investor is capable of sustaining disproportionate returns. ${ }^{98}$

Although there is significant evidence supporting the strong form of the ECMH, ${ }^{99}$ there is also evidence of some deviations from this form of market efficiency. In particular, studies have indicated that insider trading, ${ }^{100}$ presumably based upon nonpublic information regard-

Relationship Between Accounting Changes and Stock Prices: Problems of Measurement and Some Empirical Evidence, supra note 96, at 17-26.

98. See Stanford Note 1050-52.

99. Most tests of the strong form of the ECMH look to the rates of return realized by investors who might be expected to have access to nonpublic information. A finding that such investors are consistently able to earn rates of return superior to those of the average investor would tend to undermine the strong form ECMH. However, with the possible exceptions of insider and specialist trading, discussed at text accompanying notes 100-01 infra, numerous studies have failed to reveal any group of investors who consistently earn disproportionate returns by virtue of access to nonpublic information not already reflected in stock prices. For example, mutual funds are normally supported by teams of sophisticated and comprehensive securities analysts who, by virtue both of their financial sophistication and of their proximity to information sources, might be expected to have access to significant amounts of information unavailable to the general investing public. Yet studies have found that mutual funds do not, on the average, yield returns any higher than the market as a whole. See, e.g., House Comm. on INTERSTATE AND ForeigN Commerce, A Study of Mutual Funds H.R. Rep. No. 2274, 87th Cong., 2d Sess. (1962); I. Friend, M. Blume \& J. Crockett, Mutual Funds and Other Institutional Investors, A New Perspective (1970); Jensen, Risk, The Pricing of Capital Assets, and the Evaluation of Investment Portfolios, 42 J. Bus. 167 (1969); Jensen, The Performance of Mutual Funds in the Period 1945-1964, 23 J. FinANCE 389 (1968); Sharpe, Mutual Fund Performance, 39 J. Bus. 119 (1966); Williamson, Measurement and Forecasting of Mutual Fund Performance: Choosing an Investment Strategy, Financial ANalysts J., Nov.-Dec. 1972, at 78. See generally Lorie \& Hamilton 8797.

100. See the authorities cited in Stanford Note $1052 \mathrm{n} .105$ for evidence of profitable trading by insiders. Although these studies would seem to indicate that insiders can earn above-average returns when trading on inside information, it is important to note that a given insider is unlikely to be capable of sustaining disproportionate returns for any length of time, both because he cannot always expect to be in possession of valuable information and because he must take great precautions not to run afoul of the series of court decisions in recent years imposing strict sanctions on insider trading. See, e.g., Shapiro v. Merrill Lynch, Pierce, Fenner \& Smith, Inc., 495 F.2d 228 (2d Cir. 1974); Financial Indus. Fund, Inc. v. McDonnell Douglas Corp., 474 F.2d 514 (10th Cir.), cert. denied, 414 U.S. 874 (1973); SEC v. Texas Gulf Sulphur Co., 401 F.2d 833 (2d Cir. 1968), cert. denied, 394 U.S. 976 (1969). Thus, when compared with the aggregate volume of trading on the stock market, insider trading poses a relatively minor deviation from strong form market efficiency. 
ing a firm's future prospects, as well as upon trading by NYSE specialists ${ }^{101}$ whose special status provides exposure to nonpublic information indicating the likely direction of future stock prices, does in many instances give rise to rates of return higher than those experienced by the market as a whole. However, these minor deviations from the general model of the strong form ECMH do not significantly alter the fact that, in general, the market conforms to the ECMH.

Implicit in the above discussion of the ECMH are three basic assumptions: first, that investors operate within the same time horizons and have homogeneous expectations with regard to prices; second, that investors have access to the market on equal terms (that is, transaction costs are the same for everyone); and third, that information is available at little or no cost to all interested parties. ${ }^{102}$ These "ideal" characteristics are obviously not entirely present in any existing market. However, in order for there to be an efficient market, there must be some approximation of these conditions. One commentator has stated that it is sufficient, absent agreement regarding the implications of current information and expectations regarding price movements, that there be no evidence of consistently superior or inferior performance by significant participants in the market, that transaction costs be "reasonable" and that information be available to a "sufficient" number of investors. ${ }^{103}$

Any significant departure from these conditions threatens to result in an inefficient market in which stock prices imperfectly reflect available information, a situation that facilitates the existence of mispriced stocks. A market characterized by a widespread nonhomogeneity of expectations as to price, caused by a sharp divergence of views as to the appropriate method of stock valuation, will contain mispriced stocks as a result of conflicting and often incorrect analysis of available information. Similarly, if investors with transaction costs significantly less than other investors engage in a substantial amount of market activity, prices will reflect not only generally available information but also special advantages enjoyed by certain investors, and the stock will be mis-

101. See Niederhoffer \& Osborne, Market Making and Reversal on the Stock Exchange, $61 \mathrm{~J}$. AM. STATISTICAL ASs'N 897 (1966) (concluding that NYSE specialists are able to earn aboveaverage returns by virtue of their access to information about market price structure). NYSE specialists are legally entitled to use this information when trading for their own account in market-making, and they are neither required nor allowed to disclose it to investors in general. See generally Wolfson \& Russo, The Stock Exchange Specialist: An Economic and Legal Analysis, 1970 Duke L. J. 707 for a discussion of the stock exchange specialist system. Again, however, this represents only a minor deviation from strong form market efficiency.

102. See note 85 supra. See Lorie \& Hamilton 80; Stanford Note 1040 n.38.

103. Fama, supra note 70 , at $387-88$. 
priced. Finally, where access to investment information is restricted, either absolutely or by virtue of cost considerations, there is clearly an impediment to the rapid adjustment of the market to reflect such information. This presents the opportunity for those in possession of such information to take advantage of the delayed market reaction in order to realize superior gains. ${ }^{104}$

\section{B. How Tender Offer Arbitrage Impairs the Efficiency of the Market.}

The announcement of a tender offer should not, in itself, have any effect on the efficiency of the market. The participation of arbitrageurs in the tender offer process, however, does operate to impair the efficiency of the market, resulting in overpriced target stock.

With the announcement of a tender offer, complications enter the valuation process for target stock because thereafter stock prices reflect not only "investment potential" but also the possibility of obtaining a premium for shares tendered to the offeror. If arbitrageurs were not involved, the market, under the ECMH, should be expected to reflect this new factor rapidly, offset by the risks involved in the tender offer. Thus, market price will rise, but not to the level of the tender price. ${ }^{105}$

Since, absent arbitrage, the basic assumptions underlying the ECMH remain in force, the market remains efficient. Investors' expectations certainly change with the introduction of a new factor into the valuation process, but the key point is that expectations change uniformly because all investors are faced with the same decision. Homogeneity of expectation therefore persists. Likewise, since transaction costs to investors are not affected, access to the market is available on the same terms as before the offer. Finally, the practical necessity of communicating the terms of the offer to target shareholders, as well as SEC disclosure requirements, makes information regarding the terms and conditions of the offer immediately available to the public.

When arbitrage enters the picture, however, the natural efficiency of the market is disrupted, because large-scale arbitrageur participation runs counter to several of the underlying assumptions of an efficient market.

First, arbitrageur intervention destroys homogeneity of expectation among target shareholders. Those shareholders not involved in arbitraging the transaction (the "investors") must consider the value of the stock as a continuing investment should the tender offer fail, its

104. See text accompanying note 98 supra.

105. Note that the market price may rise above the tender price if competing offers are likely. See notes 33-34 supra and accompanying text. 
value as a continuing investment should the shareholder not tender and the offer nevertheless succeed, its value if tendered and accepted, its value if tendered and prorated, and its value on the market. The arbitrageur's expectations, on the other hand, are much simpler. He ignores the investment potential of the stock (except as a factor in his initial evaluation of the chances of success for the offer), because he has no intention of becoming an "investor." 106 The arbitrageur's sole concern is what he can earn by tendering his stock. This nonhomogeneity of expectations among investors and arbitrageurs necessarily gives rise to inconsistent valuations of target stock by investors and arbitrageurs.

Second, the assumption that investors have equal access to the market is violated because arbitrageurs are able to avoid a substantial part of the transaction costs paid by investors ${ }^{107}$ and in most cases can rely on ultimately receiving a soliciting dealer's fee. ${ }^{108}$ This in effect guarantees arbitrageurs a price higher than that available to investors for tendered stock. Thus, unlike the normal situation where transaction costs have a slight overall impact upon the market, ${ }^{109}$ the virtual absence of transaction costs to the arbitrageur allows him to exploit small per-share differentials on a large volume scale in situations where the ordinary investor's profit margin would be entirely absorbed by transaction costs. This one-two punch, consisting of lower costs to acquire target stock, coupled with higher proceeds upon tendering, allows arbitrageurs profitably to bid higher for target stock than investors, contributing to the overpricing of target stock, and, hence, to the inefficiency of the market.

The combination of differing expectations among investors and arbitrageurs and unequal access to the market creates target stock that is overpriced from the perspective of the investor. Arbitrageurs tend to dominate purchases on the market during pendency of the tender offer because they are willing (due to differing expectations) and able (be-

106. The arbitrageur intends to hold his target stock only long enough to tender it and has no desire to ride the market. See, e.g., Huge Profits Out of Tiny Margins, supra note 1, where the author observes that arbitrageurs "intensely dislike ordinary trading-even more than they dislike taking losses. 'If you're caught when a merger falls through, then you become-' and Greenburg [a leading arbitrageur] shudders at the word-'an investor.'" Id. 120.

107. See note 130 infra and accompanying text.

108. See note 131 infra and text accompanying notes 131-33 infra.

109. In a typical investment situation, where the investor holds stock for several years, collects dividends and perhaps ultimately disposes of his holdings at a gain, the brokerage commission costs incurred by the investor will likely be a relatively insignificant percentage of the total income produced by the investment. In an arbitrage situation, however, where profitability lies in the ability to exploit small per-share differentials on a volume scale, any cost which eats into that small per-share margin will have a major impact upon profitability. 
cause of price advantage) to pay more than the value of the stock to the general investing public.

The following sections of this Comment will examine the effect of this diagnosed market inefficiency upon the balance of tender offer regulation and upon the economy as a whole.

\section{Tender Offer Arbitrage and the Regulatory Balance.}

The Williams Act amendments ${ }^{110}$ to the Securities Exchange Act of $1934^{111}$ were enacted in response to perceived inequities in the tender offer process. The Williams Act was intended to strike a balance between offeror and target management, so that neither would possess a distinct advantage solely by virtue of its position. ${ }^{112}$ The provisions of the Act attempt to provide both sides with equal access to target shareholders for the purpose of presenting information relevant to an evaluation of the merits of the outstanding offer, while imposing concomitant disclosure requirements. ${ }^{113}$ Additionally, the Act was designed to remove some of the pressure to tender from the tender offer process by establishing a mandatory period during which tendered shares could be withdrawn and by abolishing first-come, first-served offers. ${ }^{114}$ The apparent logic of the Act is that informed investors in an

110. Pub. L. No. $90-439,82$ Stat. 454 (1968) (amending 15 U.S.C. $\$ \S 781-78 \mathrm{n}$ (1964)).

111. 15 U.S.C. $\$ \$ 78 \mathrm{a}-78 \mathrm{kk}$ (1976).

112. The Senate report accompanying S. 510 noted that "extreme care" was taken "to avoid tipping the balance of regulation either in favor of management or in favor of the person making the takeover bid." S. REP. No. 550, 90th Cong., lst Sess. 3 (1967); accord, H.R. REP. No. 1711, 90th Cong., 2d Sess. 4 (1968).

Likewise, Senator Williams advocated neutrality between offeror and target management, stating "[w]e have taken extreme care to avoid tipping the scales either in favor of management or in favor of the person making the takeover bid. S. 510 is designed solely to require full and fair disclosure for the benefit of investors." 113 CONG. REC. 24664 (1967) (remarks of Sen. Williams).

Manuel Cohen, then chairman of the SEC, testified at the hearings on S. 510 that "the principal point is that we are not concerned with assisting or hurting either side. We are [only] concerned with the investor ...." Hearings on S. 510 Before the Subcomm. on Securities of the Senate Comm. on Banking and Currency, 90th Cong., 1st Sess. 178 (1967).

113. The offeror is required to make extensive disclosures, pursuant to 15 U.S.C. $\$ \S 78 \mathrm{~m}(\mathrm{~d})(1)$, $78 \mathrm{n}(\mathrm{d})(1)$ (1976), prior to launching a tender offer, and target management is also required to make disclosures, pursuant to 15 U.S.C. $\$ 78 n$ (d)(4) (1976), before recommending to its shareholders acceptance or rejection of the offer.

114. See 15 U.S.C. \& 78n(d)(5)-(6) (1976). Terms such as these were thought to increase pressure on shareholders to tender before they could be exposed to the often-conflicting views of incumbent management by creating the fear that any delay in tendering would result in the shareholder being left out. Hayes \& Taussig state that "if [the offeror] is allowed to accept shares on a first-come, first-served basis, he may encourage stockholders to tender their shares before they can be reached by the blandishments of the incumbents or rival bidders." Hayes \& Taussig, supra note 25 , at 141 . Swanson observes that "[t]he advantage of using the first-come-first-served method of acceptance is that the shareholders will be prone to rush immediately to tender their shares in order not to be left behind." Swanson, supra note 25, at 436. 
unpressured environment will reach the correct conclusion as to the merits of an offer. ${ }^{115}$

One may assume, consistent with the apparent views of Congress in enacting the Williams Act, that, absent the effects of arbitrage, the rational investor will base his decision whether or not to tender upon an evaluation of the merits of the offer. The investor will have a stronger incentive to ascertain whether the terms of the offer are fair and adequate and whether the offer is in the best interests of the target company. It is not a foregone conclusion that the investor will tender. $\mathrm{He}$ is more concerned with obtaining a suitable long-term rate of return on his capital (as opposed to a quick, one-time profit) and might well be thoroughly satisfied with his present investment. In many cases, therefore, there is a significant possibility that the investor will choose not to tender. If the target stock is held by investors (as opposed to arbitrageurs), this possibility translates into a substantial risk that the tender offer will not succeed.

In contrast, the presence of large-scale arbitrage in a tender offer creates pressure upon shareholders to sell without regard to the merits of the offer itself, tipping the balance in favor of offerors, in direct conflict with the intent of the Williams Act. The arbitrageur's only purpose in accumulating a position in the target company is that of subsequently tendering for a profit. With regard to the stock in his possession, there is no risk that the arbitrageur will not tender. It is easy to see that, as the arbitrageurs corner a significant share of the market, the character of the risk involved is altered. As the success of the offer becomes more likely, arbitrageurs can afford to pay more for target stock in light of diminished risks, and the pressure upon investors to sell is progressively escalated. At some point, the arbitrageurs may acquire such a large share of the market that the risk of failure of the offer is virtually nil, and the only remaining risk is that of proration.

The crucial point to be drawn from the above discussion is not that arbitrageurs remove the risk from the market during a tender offer, for in fact they also must allow for risk. Rather, arbitrageur participation

115. See 15 U.S.C. $§ 78 \mathrm{~m}$ (d)(1)(1976). Senator Williams, when introducing the Williams Act on the Senate floor, stated: "This legislation will close a significant gap in investor protection under the Federal securities laws by requiring the disclosure of pertinent information to stockholders when persons seek to obtain control of a corporation by a cash tender offer . . ." 113 CONG. REC. 854 (1967) (remarks of Sen. Williams).

Likewise, Manuel Cohen, then chairman of the SEC, testified before the Senate Banking and Currency Subcommittee on Securities: "[T] he general approach of . . . this bill, is to provide the investor, the person who is required to make a decision, an opportunity to examine and to assess the relevant facts . . . Hearings on S. 510, supra note 112, at 15. 
implies that the risk itself is diminished, thus allowing for an upward shift in the market for target stock, in many cases to levels in excess of the tender price. ${ }^{116}$ This price movement creates an intense pressure on investors to sell into the market without regard for the underlying merits of the tender offer and, hence, to sell into the hands of the arbitrageurs. The arbitrageur can offer a price that investors, who presumably are seeking to avoid risk, simply cannot afford to ignore. Restated in terms of ECMH analysis, the investor in an inefficient market who is in possession of a stock identified as overpriced has but one rational choice-sell!

The role of institutional investors should be emphasized in assessing the impact of the pressures generated by arbitrage. In recent years, institutional investors such as mutual funds, insurance companies, pension plans and trust departments have come to own increasingly large portions of outstanding securities. ${ }^{17}$ Such investors tend also to be more active in trading than are their noninstitutional counterparts. ${ }^{118}$ Typically, institutional investors will be interested in the riskless alternative offered by the arbitrageur. They have no desire to see their funds tied up for long periods of time in a contest for control; they are usually grateful to be given the chance to avoid the difficult decision of whether or not to tender. ${ }^{119}$ Insofar as arbitrageurs make a market for

116. See note 33 supra and accompanying text.

117. See R. Jennings \& H. Marsh, Securities Regulation 24-33 (3d ed. 1972) (quoting from an SEC study of institutional investors indicating the shift between 1952 and 1968 of large equity holdings from the hands of individuals into the hands of institutional investors).

118. Id. 14-23.

119. Where the institutional investor owns a block of common stock in the target corporation, and nothing more, its wisest course in the event of a tender offer is normally to sell on the market (into the hands of the arbitrageurs) and to reinvest its capital elsewhere. This alternative is typically more favorable to the institutional investor than is tendering because it avoids the possible delays which a contested tender offer might occasion (effectively tying up the institutional investor's capital) and also circumvents the adverse financial consequences of proration if more shares are tendered than will be taken under the terms of the offer. These adverse financial consequences are two-fold. First, the investor may be forced to sell his unaccepted shares at a loss on a falling market or else to occupy the status of minority shareholder at the mercy of the policies of a new and perhaps hostile management. Second, the investor may suffer adverse tax consequences if the cash offer is followed by a reorganization within the meaning of I.R.C. $\& 368(a)(1)$. If a merger occurs within a short period after the tender offer, then the two transactions may be deemed one for tax purposes, in which case target shareholders whose earlier tender was prorated may well be viewed as having received offeror stock and boot in the form of cash. Under I.R.C. \& 356(a)(2), such an unfortunate shareholder may then be taxed at ordinary income, as opposed to capital gain, rates. See Possible Traps for Shareholders in Tender Offers, 28 J. TAx. 256 (1968). A sale on the market will, however, avoid this problem and assure capital gain treatment.

The institutional investor's position is more complicated when its involvement with the target extends beyond mere ownership of common stock and includes, for example, ownership of preferred stock, bonds, notes or debentures, or involves other relatively long-term loan commitments to the target corporation. In such a case, the institutional investor is between the proverbial rock 
large blocks of shares held by institutional investors, arbitrage contributes substantially to the successful outcome of tender offers.

By way of empirical observation, the pressure exerted by arbitrageurs is effective in most cases. It is estimated that arbitrageurs often surface with more than one-half of all target stock tendered. ${ }^{120}$

\section{The Potential Consequences of The Regulatory Imbalance.}

Accepting the premise that pressure exerted by arbitrageurs on investors has the effect of enhancing the tender offer's chances for success, it follows that many (if not most) tender offers succeed for reasons only tangentially related to the merits of the offer itself. Because of the profound impact arbitrage has on the underlying chances for success of the tender offer, it is virtually impossible to say which offers would fail but for the effect of arbitrage. The fact that the riskless price offered by arbitrageurs was deemed sufficient by investors says nothing about the manner in which investors would have reacted had the market remained at the lower level it would have occupied absent the effect of arbitrage. Nevertheless, it is safe to say that in many cases such an offer might not have succeeded on its merits and may thus be regarded as "artificially induced" by arbitrage.

Artificially induced takeovers may produce long-term deleterious effects upon the economy. Such takeovers lend support to a widespread public sentiment that the conglomerate corporate structure of our economy is becoming top-heavy, unmanageable and unresponsive. The effect of takeovers in recent years is aptly illustrated by considering the fate of the "vanishing Fortune 500." 121 The occurrence of unmerited

and the hard place. The investor with substantial loan commitments to the target will often have a cozy arrangement with target management which it does not desire to see disrupted. Moreover, it may have legitimate reasons for not wishing to tender, even at a healthy premium, when such a course of action would entail loss of voting influence in the target corporation and would in effect leave the investor's nonvoting nonequity interests in the target at the mercy of a new and possibly hostile management team. Yet, if the investor does not tender or sell, it may have to deal with a lawsuit by one of its shareholders or beneficiaries alleging a breach of fiduciary duty arising from its failure to cash in on the premium proffered by the offeror. Although the institutional investor might well win such a suit, the bottom line is that it does not relish the thought of being put in the position of defending such a suit in the first place. Often, when faced with this dilemma, the institutional investor will opt for selling its shares on the market as the safest course of action, even though it means relinquishing any voting power formerly held in the target. Interestingly, institutional investors, who live in perpetual fear of finding themselves in the above dilemma, are at present one of the more powerful special-interest factions pushing for legislation aimed at tightening existing controls on the tender offer process.

120. See Henry 466; O'Boyle, supra note 42, at 866; of. Huge Profits Out of Tiny Margins, supra note 1 , at 116 (observing that arbitrageurs sometimes emerge with more than $90 \%$ of the stock exchanged in a merger).

121. In recent years, many of the top corporations in this country have been absorbed by 
takeovers solely through the force of arbitrage also poses the threat of replacing qualified management with less qualified successors, contributing to a misallocation of resources in the economy. ${ }^{122}$ Moreover, artificially induced takeovers do not generate significant amounts of economic growth in terms of new business or new jobs. ${ }^{123}$ They do, however, generate enormous costs in the form of litigation, information dissemination and related expenses. ${ }^{124}$ These costs are ultimately borne by the economy as a whole, thus decreasing the overall return on capital.

The psychological impact of such takeovers on the business community should not be lightly dismissed. The knowledge that everyone is a potential target, subject to being devoured in an artificially induced takeover, contributes to an atmosphere of fear, distrust and secrecy

tender offers and mergers. In 1977, for example, more than 100 publicly listed companies lost their independence as a result of takeovers. See Kissinger, Against Forced Takeovers, N.Y. Times, Jan. 22, 1978, $§ 4$, at 19, col. 2. The forced takeover process has even triggered concern in the antitrust area:

antitrust experts in Washington have begun to worry over the concentration of economic power that results from such mergers. Perhaps more important, there are growing fears that the rash of takeovers may actually distort the nation's economy as companies use their funds to acquire others rather than invest in new plants and equipment to create new jobs and improve productivity.

The Merger Rage, NEwsweEx, Oct. 16, 1978, at 88.

122. Consider the remarks of one corporate executive officer:

In reality, it is not the backward, unproductive company that is sought in the tender process. The records of Copperwell, Microdot, Carborundum and others were excellent. Rather, today's raiders focus on the more successful enterprise whose record of growth makes it an attractive target. Given this fact, is the shareholder who is rarely as well equipped as the aggressor to evaluate a company's potential, likely to benefit by being removed from long-term ownership in return for an immediate premium?

....

Once a takeover has been accomplished, destruction of the chemistry within a highly motivated management team tends to be as inevitable as it is disheartening. I question whether the resulting curtailment of a company's momentum is compensated for by so-called synergistic benefits. Numerous interviews with those who have been through it confirm my conviction that it is not.

Kissinger, supra note 121 , at 19.

123. The takeover process in itself accomplishes nothing more than a shift in control of the enterprise. It neither wins new customers nor creates new jobs; in many cases, it does precisely the opposite. Although the proponents of forced takeovers claim that such acquisitions do create economic growth in the form of synergistic benefits (i.e., the notion that $1+1=3$ ), such a claim is, at best, dubious and probably is offset by the disruptive effects occasioned where a highly successful company is overrun by an acquisition-minded offeror. See note 122 supra.

124. According to Kissinger, in 1977 alone

[m]ore than $\$ 20$ billion of corporate cash resources that could have been used to create new production and employment opportunities will have instead been devoted to rearranging the ownership of existing properties.

....

The unproductive use of time and legal fees is enormous, and the negative impact on people's lives within the target company can be severe.

Kissinger, supra note 121, at 19.

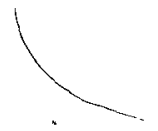


among corporate managements ${ }^{125}$ - a phenomenon fundamentally in conflict with the basic premise of an efficient marketplace that information should be freely available to investors. ${ }^{126}$

\section{E. The Case for Elimination of Windfall Premiums to Target Shareholders and Arbitrageurs.}

Clearly, many target shareholders receive windfall premiums when they sell to the arbitrageurs. The windfall consists of the portion of the price received by the shareholder that results from overpricing in an inefficient market, or, stated alternatively, consists of the increment in market price attributable to diminished risk by virtue of arbitrageur participation in the offer. Likewise, the arbitrageur clearly realizes huge profits from his activities. It is appropriate to question the legitimacy of these windfall premiums.

A leading defense for arbitrage has always been that it does not hurt the target shareholders. Perhaps the question should be whether it helps them too much. Certainly, one of the primary goals of the securities laws in general, and the William Act in particular, is investor protection. ${ }^{127}$ There is, however, a distinction between protecting the investor and guaranteeing him the right to reap a windfall profit. At some point, it becomes myopic to view securities legislation as aimed solely at improving the investor's position. One must also examine effects on the economy as a whole.

The existing tender offer legislation was intended to strike a balance, in light of which a tender offer would succeed or fail on its own merits after an opportunity for careful consideration by the target shareholders. ${ }^{128}$ Absent the interference of arbitrage, this is arguably what would happen. ${ }^{129}$ This process, in an efficient market, is itself

125. See generally id. Indeed, as Kissinger notes, most of the recent commentary on the takeover phenomenon tends to ignore entirely the issue of the basic equities involved, particularly as it relates to incumbent management, who might well have performed excellently in developing the target into a successful operation only to find themselves suddenly out of work, the victims of a takeover facilitated by the present imbalance of tender offer regulation.

This growing sense of the basic inequity, in many instances, of forced takeovers has led many corporate executives to begin taking an active role in pressing for increased regulation of tender offers. See, e.g., Letter from R. Eberstadt, Jr., President and Chief Executive Officer of Microdot, Inc., to Chief Executive Officers of FORTUNE 1000 companies (Mar. 5, 1976), reprinted in J. FLOM, M. Lipton \& E. STEINBERGER, supra note 58, at 278-81.

126. See text accompanying note 102 supra.

127. See Piper v. Chris-Craft Industries, Inc., 430 U.S. 1, 22-35 (1977). See notes 112-15 supra and text accompanying notes $110-15$ supra.

128. See notes 112-15 supra and accompanying text.

129. Were the target shareholders not under economic pressure (generated by arbitrage) to take the easy way out, i.e., to sell on the market at a premium, they would be forced to confront the merits of the offer. That result would not only be consistent with the congressional objective 
sufficient protection for the investor. When arbitrage enters the picture, the balance is tipped, giving rise to deleterious long-term economic consequences, and shareholders are permitted to enjoy windfalls that cannot fairly be argued to have been intended by the securities laws.

Moreover, the uniquely advantageous position held by most arbitrageurs legitimates the need for heightened regulation of their activities. In particular, arbitrageurs enjoy commission advantages when purchasing and selling on the New York Stock Exchange (NYSE), they typically collect a soliciting dealer's fee for shares tendered and they are in a position to unload quickly if the offer falls through. Most professional arbitrageurs own seats on the NYSE and act as brokerdealers on their own account, thereby avoiding broker-dealer commissions (which comprise the bulk of transaction costs) while paying only obligatory transfer taxes and specialist fees. ${ }^{130}$ Furthermore, the terms of most tender offers provide for the receipt by broker-dealers of a soliciting dealer's fee for all shares tendered (including those on their own account) upon execution of a soliciting dealer's agreement. ${ }^{131}$

of providing investors with full disclosure so as to facilitate their arrival at an informed decision, but would also benefit the economy by helping to insure that only meritorious takeovers occur.

130. See ARANOw \& EINHORN 175 n.S. The average investor, who is not a member of the stock exchange, must employ a broker-dealer to make his purchases and sales on the market and must pay a commission which includes a fee for the broker as well as floor brokerage charges (specialist's fees) if the transaction is handled through a specialist. See R. JENNINGS \& H. MARSH, supra note 117 , at $690-711,731-33$ for a discussion of the specialist system employed by the NYSE.

Formerly, such fees were fixed by stock exchange rules; however, due to anti-competitive effects and possible antitrust violations, the SEC promulgated Securities Exchange Act Rule 19b3, prohibiting fixed commission rates. 17 C.F.R. \$ 240.19b-3 (1977). See Exchange Act Release No. 11203, [1974-1975 Transfer Binder] FED. SEC. L. REP. (CCH) \& 80,067 (describing the new rule and the reasons for its promulgation). In a follow-up report to Congress, the SEC observed that the primary impact of the unfixing of commission rates was a reduction of commission costs to institutional investors. The SEC estimated commission costs to institutional investors, in cents per share, as averaging 17.6 cents in September 1976 and 17.2 cents in November 1976. Comparable figures for individual investors were 29.4 cents and 27.5 cents, respectively. See Summary of Securities and Exchange Commission's Fourth Report to Congress on the Effect of the Absence of Fixed Rates of Commissions, [1976-1977 Transfer Binder] FED. SEC. L. REP. (CCH) If 80,934. This differential between institutional and individual investors is most likely due to the brokers' increased willingness to negotiate with institutional investors, which provide an ever-increasing share of their business and which typically trade in larger blocks of stock than individuals, giving rise to economies of scale for the broker.

131. A soliciting dealer is a broker-dealer who, in return for a fee, will agree to act as a "middleman" of sorts in a tender offer, collecting tendered shares from target shareholders and turning them over to the offeror. For reasons to be discussed at text accompanying note 133 infra, most tender offers make provisions for payment of a fee to soliciting dealers. See, e.g., Colt Industries, Inc., Offer to Purchase Any and All Outstanding Shares of Common Stock of Garlock, Inc., for Cash at \$32 Per Share Net, reprinted in J. FLOM, M. LIPTON \& E. STEINBERGER, supra note 58, at 408: 
Such arrangements have been uniformly upheld against challenges based on rules $10 \mathrm{~b}-6$ and $10 \mathrm{~b}-13$ in recent SEC no-action letters, provided the arbitrageur fully ceases his arbitrage activities prior to executing the soliciting dealer's agreement. ${ }^{132}$ It is logical to suppose that such provisions will continue to appear in tender offers, insofar as the surest way to guarantee the success of a tender offer is to get the arbitrageur on your side, and the surest way to win the arbitrageur is by appealing to his pocketbook with a healthy soliciting dealer's fee. ${ }^{133}$ Indeed, in many cases offeror management, when faced with the choice between upping the offer price or the soliciting dealer's fee, will opt for the latter.

In addition, it is essential, in the event the offer fails, that the arbitrageur be in a position to unload target stock quickly so as to minimize losses. Membership on the NYSE greatly facilitates this required ease of access to the market. ${ }^{134}$

All of these advantages are traceable to the arbitrageur's status as a broker-dealer and member of the NYSE. The arbitrageurs are a select group, ${ }^{135}$ occupying a position and enjoying advantages well out of reach for the average investor. ${ }^{136}$ Cumulatively, the advantages inuring to the benefit of arbitrageurs by virtue of their near-monopoly position are necessary for their continued success and profitability. ${ }^{137}$

The Purchaser will pay to any broker or dealer . . . which is a member of a registered national securities exchange or of the National Association of Securities Dealers, Inc. . . the name of which appears in the appropriate space in a Letter of Transmittal and which has solicited the tender to which such Letter of Transmittal relates, a solicitation fee of 60 cents for each share purchased pursuant to the Offer and covered by such Letter of Transmittal . . . except that no such fee will be paid in respect of Shares tendered by a Soliciting Dealer for its own account unless beneficial ownership thereof was acquired by such Soliciting Dealer in the performance of arbitrage functions after No. vember 17, 1975.

This particular provision is somewhat unusual in that it limits a soliciting dealer's ability to collect a soliciting dealer's fee for shares tendered on its own account to only those situations where the shares were acquired after the offer was announced for the purpose of arbitraging the transaction. Thus, it indicates more clearly than most offers how the offeror can use soliciting dealer's fee provisions to attract the arbitrageur and thereby enhance the chances for success of the offer.

132. See, e.g., No-Action Letter From SEC Division of Market Regulation to Oak Industries, Inc. (Nov. 22, 1976), reprinted in [1976-1977 Transfer Binder] FED. SEC. L. REP. (CCH) I| 80,858; No-Action Letter From SEC Division of Market Regulation to Wyly Corp. (Dec. 30, 1976) (available Jan. 30, 1977). See generally ARANOw \& EINHORN 187-91.

133. ARANOW \& EINHORN 187-88. See O'Boyle, supra note 42, at 865-66.

134. See note 57 supra.

135. See note 26 supra.

136. For example, as of 1962 , there were only 1,366 memberships on the NYSE. R. JENNINGS \& H. MARSH, supra note 117 , at 5 . Add to this the fact that such seats, when and if available, sell for hundreds of thousands of dollars, and it becomes apparent that the special advantages of the arbitrageur are not within reach of the ordinary investor.

137. Because arbitrage operates on the principle of exploiting small price differentials on a 
These advantages should impose concomitant duties upon the arbitrageur, who should not be allowed to exploit his near-monopoly in derogation of the balance sought to be struck by the securities laws.

\section{The Form Proposed Regulations Should Take}

Careful consideration of the factors giving rise to the problems discussed above leads to the conclusion that the most effective mode of regulation to achieve the desired goal of reinstating a balance between offeror and target would consist of imposing across-the-board volume limitations upon purchases of target shares during the pendency of the tender offer.

Although the trend of recent Supreme Court decisions has been to indicate that full and adequate disclosure is the sole remedy proposed by the Williams Act, which should alone suffice to achieve the underlying goal of investor protection, ${ }^{138}$ disclosure would clearly be an inadequate and meaningless remedy in the arbitrage situation. First, there is nothing of substance for the arbitrageur to disclose beyond his mere status and the results of his evaluation of the particular tender offer in question. Were the arbitrageur merely to "state his name and occupation" for the record, there would be no benefit to investors and no effect on the outcome of the offer, insofar as the sophisticated investor already knows whether or not the arbitrageur is at work and his less informed fellow shareholders most likely do not care. To require the arbitrageur to make public the results of his evaluation of the offer would involve going far beyond existing requirements for disclosure of "inside information," into the realm of disclosure of "market information," a step which arguably is not justified even by a liberal reading of the securities laws and which few courts would endorse. ${ }^{139}$ Moreover, such disclosure ultimately would be futile since the results of the arbitrageur's analysis tend to be reflected almost immediately in the market price of the target stock. ${ }^{140}$ Thus, disclosure would fail to strike at the

large-volume scale, any loss of advantage which cuts into this narrow margin will have an immense aggregate effect upon the profitability of arbitrage operations. See note 109 supra and accompanying text. Were arbitrageurs to lose their special commission and soliciting dealer advantages, they would be reduced to the level of ordinary investor and would, at the very least, have to curtail their operations severely.

138. See, e.g., Piper v. Chris-Craft Indus., Inc., 430 U.S. 1 (1977); Rondeau v. Mosinee Paper Corp., 422 U.S. 49 (1975).

139. See generally Fleischer, Mundheim \& Murphy, An Initial Inquiry Into the Responsibility to Disclose Market Information, 121 U.PA.L. REv. 798 (1973), and cases discussed therein.

140. Assuming an efficient market, the conclusions reached by arbitrageurs through an analy"sis of market information would already be reflected in the market price of target stock by the time formal disclosure machinery could be set into motion. Hence, such disclosure would be essentially meaningless. 
root of the problem, which is the arbitrage activity itself. A second problem plaguing any attempt to impose disclosure requirements upon arbitrageurs would be the difficulty, if not impossibility, of formulating an adequate definition of "arbitrageur"-one which would sweep broad enough to be effective and yet would avoid ensnaring legitimate investors not involved in arbitrage. Such difficulty is aptly illustrated by analogy to the SEC's continuing inability to formulate a satisfactory all-inclusive definition of "tender offer." 141

\section{A more plausible scheme for the regulation of arbitrage activity ${ }^{142}$}

141. See Securities Exchange Act Release No. 12676, [1976-1977 Transfer Binder] Fed. Sec. L. REP. (CCH) I 80,659, at 86,695-96; ARANOw \& EinHORN 69-70; ARANOw, Einhorn \& BerLSTEIN 1-2. The SEC's reluctance to attempt a definition of the term "tender offer" is the consequence of fears that, were such a definition employed, transactions would subsequently arise which should be regulated but which could not be reached under the literal terms of the definition. A similar problem would also likely arise if a narrow definition of "arbitrage" were attempted.

142. Until very recently, any proposal for regulation of arbitrage activity would have been written on a clean slate. However, it now appears that recently issued FTC rules and regulations may have the indirect and largely unintended effect of imposing maximum limits upon arbitrageur involvement in certain offers. These new rules and regulations, effective September 5, 1978, were designed to implement the recently enacted pre-merger notification requirements of section 7A of the Clayton Act, Hart-Scott-Rodino Antitrust Improvements Act of 1976, Title I1, 15 U.S.C. $\S 18$ a (1976). See 43 Fed. Reg. 33,449-557, 34,443-53, 36,053-54 (1978) (to be codified in 16 C.F.R. $\$ \S 801-803$ ). Their basic thrust is to impose disclosure requirements and a waiting period upon certain acquisitions that exceed specified threshold amounts.

During the time these rules were under consideration, comments were received by the FTC which urged creation of an exemption for professional risk arbitrageurs. The FTC rejected these suggestions, but did hint that arbitrageurs might be entitled to the limited exemption provided for broker-dealers pursuant to $\$ 802.64$. 43 Fed. Reg. 33,519 (1978). Assuming this exemption applies, arbitrageurs would be exempt from disclosure and waiting period requirements unless their individual holdings in the target ultimately exceeded both $\$ 25$ million in value and $15 \%$ of the target's outstanding voting securities. 43 Fed. Reg. 33,547 (1978) (to be codified in 16 C.F.R. \& 802.64). Even without the exemption, individual arbitrageurs would not be affected unless their holdings equal or exceed either $\$ 15$ million in value or $15 \%$ of the target's outstanding voting securities. Clayton Act § 7A(a)(3), 15 U.S.C. § 18a(a)(3)(1976); 43 Fed. Reg. 33,539 (1978) (to be codified in 16 C.F.R. $\$ 801.1(\mathrm{~h})$ ).

Therefore, these new rules are not likely to have a significant impact on arbitrage activities in most situations. They will be relevant only where an individual arbitrageur aggregates holdings in the target in such an amount as to exceed the above thresholds. The practical effect of the rules will be that arbitrageurs will consciously endeavor not to exceed the threshold amounts. This is true for two reasons. First, even though the disclosure statement is ostensibly confidential and is available only to the FTC, the Antitrust Division of the Justice Department and Congress, arbitrageurs are notoriously secretive and in any event are unlikely to be willing to incur the time, expense and inconvenience of complying with such a requirement. Second, and more important, is the waiting period requirement. This is especially significant in a cash tender offer. Since the offeror is acquiring target shares by a cash tender offer, it will be subject only to a 15-day waiting period. 15 U.S.C. \& 18a(b)(1)(B)(1970). However, should the arbitrageur plan to exceed the threshold amounts by stock exchange purchases, he would be subject to a 30-day waiting period. Id. Thus, the offer would in many cases already have expired before the arbitrageur could legally make his first purchase of target stock. For this reason, arbitrageurs can be expected to steer clear of the threshold amounts which would subject them to the rules, and in most cases the rules will have little or no effect on arbitrageur activity. 
consists of regulations imposing a carefully thought out system of across-the-board limitations upon trading in the target stock during pendency of the tender offer. Such regulations could be modeled in part after the volume limitation formulas employed in SEC proposed rule $13 \mathrm{e}-2 .{ }^{143}$

The implementation of a system of volume limitations upon purchases would be an effective remedy for the imbalance of tender offer regulation resulting from large-scale arbitrage. Insofar as the occurrence of "artificially induced" takeovers is by definition the direct result of the tender of large blocks of target shares by a small group of professional risk arbitrageurs, ${ }^{144}$ a system of regulations that effectively prevented the accumulation of such blocks would operate to curtail or eliminate entirely such takeovers. Such an approach would have the additional virtue of avoiding the difficulties inherent in any attempt to

143. See Proposed Rule 13e-2, 17 C.F.R. § 240.13e-2 (proposed), 2 FED. SEC. L. REP. (CCF) I 23,703 (1973). This rule was first proposed in Securities Exchange Act Release No. 8930, [19691970 Transfer Binder] FED. SEC. L. REP. (CCH) I 77,837, and was later revised, due to negative comment, and reissued in Securities Exchange Act Release No. 10539, [1973 Transfer Binder] FED. SEC. L. REP. (CCH) I79,600. Although the rule has not been formally adopted, the SEC treats it as if it had been, and, consequently, most corporations comply with its provisions.

Rule 13e-2 regulates, inter alia, an issuer's repurchase of its own shares on a national securities exchange. The rule sets up basic price and volume limitations, geared to recent averages, in order to preserve the integrity of the market and to prevent an issuer from manipulating the price of its stock. Such an approach could be adapted to apply across the board during the pendency of a tender offer, in order to regulate arbitrage activities and to restore the balance between offeror and target intended by the Williams Act.

The proposed rule provides in part:

(3) Transactions in securities the principal market for which is an exchange.

(i) No bid for such securities may be made at a price higher than the highest

independent bid or last sale on such exchange, whichever is higher ....

(ii) The amount of such securities which may be purchased in any one day shall be limited to the higher of:

(a) one round lot (or other unit of trading) per day; or

(b) 15 percent of the average daily trading volume in the principal exchange market for such security during the preceding four calendar weeks; provided, however, that if such security is traded on more than one exchange, and/or over-thecounter, the amount of securities which may be purchased in any one day on each exchange or in such market may equal 15 percent of the average daily trading volume during the preceding four calendar weeks on each exchange or in such market, if the self-regulatory organization with oversight jurisdiction over such market maintains daily volume data for such security.

2 Fed. Sec. L. REP. (CCH) \23,703, at 17,244 (1973).

An approach similar to that utilized in the above-quoted section of the proposed rule may be applied to the problem of regulating purchases of target stock while a tender offer is outstanding. As in proposed rule 13e-2, the volume limits used should be based upon past trading volumes in the target stock. The precise formula employed should reflect a balancing of the competing goals of preserving the access of legitimate investors to the market, while still prohibiting excessive arbitrage activities which would substantially affect the outcome of the offer. See text preceding note 151 infra.

144. See text accompanying notes 121-26 supra for a discussion of "artificially induced" takeovers. 


\section{formulate a satisfactory working definition of arbitrage. ${ }^{145}$}

One possible objection to such a system of regulation is that it would not pose an effective check on the overall incidence of arbitrage, but rather would result only in a fragmentation of existing arbitrage operations and would create an incentive for others to enter the field and capture part of the business formerly controlled by a select few arbitrageurs. This objection can be dealt with, however, through the exercise of care in defining regulatory terms and through proper formulation of the precise volume limits to be implemented. The definition of who is to be regarded as a "person" for purposes of the regulations must be carefully drawn so as to prevent existing arbitrageurs from fragmenting their operations and continuing under the guise of several legally distinct but commonly controlled entities, or from otherwise "farming out" their arbitrage "know-how" for profit. ${ }^{146}$ This could be accomplished by defining person in a manner analogous to the approach taken in section $13(\mathrm{~d})(3)$ of the Williams Act, ${ }^{147}$ so as to include partnerships, limited partnerships, syndicates or other groups formed for the purpose of circumventing the effects of the new regulations. ${ }^{148}$ Likewise, there is little reason to fear that there will be a dramatic influx of independent arbitrage operators. If such a phenomenon where

145. See note 141 supra and accompanying text.

146. For instance, if the proposed regulations were drawn only to prevent the arbitrageur from purchasing more than a specified volume of target shares on his own account, it is conceivable that arbitrageurs would simply convert their operations so that, instead of purchasing for their own account, they would be managing the funds of other investors in a collective fashion, allocating purchases to various individual accounts in order not to exceed individual volume limitations. This practice is already engaged in by at least two major arbitrage firms which, in addition to arbitraging for their own account, will periodically take on arbitrage accounts for wealthy individuals. See Wall Street's Highest Rollers, supra note 13, at 56, where it is noted that Lehman Brothers and Sheriff Securities, Inc. both arbitrage transactions on behalf of wealthy clients, as well as for their own accounts. Similarly, arbitrageurs might set up the equivalent of an "arbitrage information service" and sell their "know-how" to investors at a healthy profit, with the investors in turn absorbing the slack created by a mandated reduction in professional arbitrageur purchases. Or, alternatively, arbitrageurs might circumvent inartfully drawn regulations by splitting their operations among several specially created shell corporations subject to common control.

These potential problems can be handled through careful drafting. See note 148 infra and text accompanying notes $146-48$ infra. Moreover, because arbitrage is an area where substantial economies of scale come into play, it is very likely that merely splitting up arbitrage operations would, in itself, substantially eliminate the effects of arbitrage by adversely affecting its profitability. See note 150 infra and accompanying text.

147. 15 U.S.C. $\$ 78 \mathrm{~m}(\mathrm{~d})(3)(1976)$.

148. Section 13(d)(3) provides:

(3) When two or more persons act as a partnership, limited partnership, syndicate, or other group for the purpose of acquiring, holding, or disposing of securities of an issuer, such syndicate or group shall be deemed a "person" for the purposes of this subsection. 15 U.S.C. $\S 78 \mathrm{~m}(\mathrm{~d})(3)$ (1976). A definition similar to the above could be adapted for use in regulations governing tender offer arbitrage, perhaps with some additional provisions applying a control test for commonly held corporations. 
going to occur, it already would have occurred. ${ }^{149}$ At present, there are a very limited number of professional arbitrageurs who dominate the field for all practical purposes. Although their ranks have increased somewhat as the profit potential has soared, there has been no dramatic influx of new participants in the arbitrage game. There is no reason to anticipate that regulation of arbitrage would reverse this tendency-on the contrary, it would most likely discourage potential arbitrageurs by severely curtailing the degree of their possible involvement in arbitrage. This is an important factor when one realizes that arbitrage owes much of its success to economies of scale. ${ }^{150}$

A further possible objection to such a system of regulation is that it might sweep too broadly by limiting purchases made by non-arbitrageurs. The answer to this criticism is that whatever volume limitations ultimately are proposed must carefully weigh the interests in regulating arbitrage against the benefits of a free and unregulated market in order to arrive at a suitable volume figure that will not impair legitimate purchasers' access to the market. This hypothetical problem therefore will not be likely to arise under a well-drafted set of regulations, except perhaps in cases where a second competing tender offer is in the wind and the second offeror attempts to purchase up to the five percent limit before announcing its offer, ${ }^{151}$ or where the target enters the market to repurchase its own shares. In the first instance, it is arguably not unreasonable to require the second offeror to proceed directly with its offer in the interest of preserving a fair and efficient marketplace. In the second situation, it remains, even at present, an unsettled legal issue the extent to which target management is free to engage in the repurchase of its own shares as a defensive tactic without

149. See Wyser-Pratte 10. There, the author notes that, throughout the years, many Wall Street firms and private investors have tried to become involved in risk arbitrage. The author concludes, however, that "[h]aving neither (a) schooling or experience in the finer points of the trade, (b) the requisite expert staffs, or [sic] (c) membership in the Community, they tend to fall by the wayside." Id.

150. See note 137 supra. Not only must the arbitrageur operate on a large-volume scale in order to realize profits from small per-share differentials, he must also keep up a large turnover so as to spread out his enormous fixed overhead costs, for example, the expense of running a large office, hiring staff, maintaining a seat on the NYSE and other related business costs.

151. At present, it is permissible to own beneficially up to five percent of a corporation's stock without having to file with the SEC. See 15 U.S.C. $\$ \$ 78 \mathrm{~m}$ (d), $78 \mathrm{n}$ (d) (1976). However, there is a movement underway to introduce new amendments to the 1934 Act, which would roll back the five percent threshold where the acquisition was part of an overall takeover scheme and was followed by a tender offer. See note 156 infra.

In addition, many offerors will in the future be subject to the waiting period and disclosure requirements imposed by a new set of FTC rules and regulations, effective September 5, 1978, issued pursuant to the recently enacted pre-merger notification provisions of section $7 \mathrm{~A}$ of the Clayton Act, 15 U.S.C. § 18a (1976). See note 142 supra. 
breaching its fiduciary duty to shareholders. In either event, should it ultimately be determined that offerors and targets merit special treatment, there will be ample opportunity to provide carefully drafted regulatory exemptions to address specific objections. ${ }^{152}$

A final point pertaining to the proposed regulation of arbitrage is the observation that additional congressional enabling legislation will most likely be required to give the SEC power to promulgate rules that will be upheld by the courts. The regulations proposed here differ from proposed rule $13 \mathrm{e}-2$ in that they lack explicit statutory support. ${ }^{153}$ Even with such general support as rule 13e-2 finds in section 13(e)(1) of the 1934 Act, ${ }^{154}$ these regulations might be found to be beyond the SEC's scope of authority under a reading of recent Supreme Court decisions that appear to narrowly construe the securities laws as aimed at providing only for disclosure and not for substantive regulation, unless expressly authorized. ${ }^{155}$ For this reason, it is suggested that if Congress undertakes to reamend the Williams Act so as to overrule the Supreme Court's decision in Piper v. Chris-Craft Industries, Inc., ${ }^{156}$ it

152. This Comment does not purport to address the complex problems which may arise in attempting to create specific regulatory exemptions designed to remedy situations where application of the general rule would be unwarranted. It instead assumes that such situations, if they do arise, will be most appropriately handled by the SEC during the course of its formulation of arbitrage regulations.

153. Proposed rule 13e-2 finds statutory support in section 13(e) of the 1934 Act, 15 U.S.C. \& $78 \mathrm{~m}$ (e) (1976), which provides, inter alia, that the SEC has the authority to promulgate rules and regulations to define and prevent fraudulent, deceptive or manipulative acts and practices on the part of issuers of securities registered with the SEC. There is no such explicit support for rules which would impose similar restrictions on purchases by anyone while a tender offer is outstanding. At best, such rules could be said to find support in section 10(b) of the 1934 Act. 15 U.S.C. \& 78j(b) (1976). However, recent Supreme Court decisions most likely foreclose such an argument, absent new congressional legislation. See note 156 infra and accompanying text.

154. 15 U.S.C. $\$ 78 \mathrm{~m}(\mathrm{e})(1)$ (1976). See note 153 supra.

155. See cases cited at note 138 supra.

156. 430 U.S. 1 (1977). It is likely that new amendments to the 1934 Act will be introduced in the Senate in the fall of 1978 . The focus of these amendments will be upon tightening existing regulation of tender offers and correcting what is rightly perceived as an imbalance of regulation favoring the offeror. Such legislation likely will provide for advance notice of tender offers, will roll back the five percent threshold filing requirement discussed at note 151 supra and will reinstate private standing to enforce the provisions of the act, thus effectively overruling the ChrisCraft decision. Present dissatisfaction with the existing state of tender offer regulation is indicated by the remarks of Senator Harrison Williams, sponsor of the Williams Act, in the introduction to ARANOW, EINHORN \& BERLSTEN:

[Recent] Supreme Court decisions have had a mixed effect on the attainment of the purposes and policies of the federal securities laws in general, and the tender offer provisions in particular. While some of the Court's decisions have clarified troubling uncertainties in the application of the federal securities laws, other decisions may have substantially changed the contours of litigation under the tender offer statutes in a manner never intended or envisioned by the Congress.

Chris-Craft is a graphic illustration. Since 1968, tender offerors have been bringing suits against targets, and targets against offerers, to enforce the statute. Few questions were ever raised as to standing. Early in 1977, however, in Chris-Craft the Court denied 
should also give serious attention to including provisions that would enable the SEC effectively to regulate tender offer arbitrage activity.

\section{Conclusion}

The propriety of the activities of arbitrageurs has not heretofore been seriously questioned. Their participation in tender offers has been regarded as largely beneficial insofar as it provides target shareholders with a riskless alternative to tendering at a more than adequate price. Arbitrageurs have been thought to absorb the risks of the tender offer and facilitate the smooth transition of the market. Their profits have been viewed as not incommensurate with the risks taken.

This traditional view of arbitrage fails to account for the unbalancing influence of arbitrage on existing tender offer regulation and the potential long-term deleterious economic consequences that arise from such imbalance. The participation of arbitrageurs in a tender offer fundamentally alters the risks bearing upon the success of the offer, changing its attractiveness to investors. Arbitrageurs can and do offer prices higher than those which the market would normally fix by its unbiased operation, exerting an intense and often successful pressure upon investors to sell into the hands of arbitrageurs, who are committed to tendering without regard for the underlying merits of the offer. This results in an imbalance of tender offer regulation favoring the offeror and creates the possibility of takeovers "artificially induced" by arbitrage. The long-term consequences of a system of regulation which facilitates such importunate takeovers include replacing efficient managements with inefficient successors, creating enormous costs unrelated to productive economic activity, aggravating the "top-heavy" tendency of corporate structures and contributing to an overall atmosphere of fear, distrust and secrecy among the business community inimical to the basic goals of the securities laws.

The parties benefitted by arbitrage have no special claim to protection. Target shareholders, many of whom are currently receiving a windfall from the arbitrageur, would be adequately protected by the unbiased operation of the market absent the effects of arbitrageur inter-

tender offerors standing to obtain damages for violations of the statute. Unquestionably, this decision will have profound implications for future tender offer litigation. In my view, the questions raised were serious enough to warrant consideration of whether new legislation is required to reestablish the balance between offerors and targets, and to ensure that the tender offer laws are effectively enforced. Id. xviii.

The author believes that the legislation necessary to enable the SEC effectively to regulate tender offer arbitrage is easily capable of being engrafted upon legislative efforts which may currently be underway. 
vention. The arbitrageurs themselves, while admittedly taking risks, are nevertheless realizing returns incommensurate with those risks. Moreover, such returns can be consistently realized only because of the arbitrageurs' unique and near-monopolistic status. These advantages, enjoyed by arbitrageurs but unattainable by the average investor, give rise to a need for regulation of arbitrage activity.

Disclosure is not the answer because there is nothing of substance for the arbitrageur to disclose. Moreover, disclosure would not get at the root of the problem, which is the arbitrage activity itself. Rather, what is needed is a system of volume restrictions upon purchases analogous to those outlined in proposed SEC rule 13e-2. In the case of arbitrage, such restrictions would be applicable to all purchases on the market while the tender offer is outstanding, thus accomplishing the two-fold objective of preventing arbitrageurs from acquiring blocks of shares sufficiently large to control the outcome of the tender offer while avoiding the problems which would accompany any attempt to define arbitrage and to formulate regulations applicable only to arbitrageurs so defined. By careful drafting, the proposed regulations can effectively check the effects of arbitrage and prevent arbitrageurs from merely splintering their operations and continuing unabated. Likewise, through the exercise of care in arriving at the level of regulation, the desired results can be achieved without unduly restricting the access of legitimate investors to the marketplace. Thus, the major focus of future debate should center around the desirable degree of regulation of arbitrage-whether it should be partially curtailed or entirely eliminated.

In the meantime, Congress should enact legislation granting the SEC authority to adequately and effectively deal with this problem by promulgating rules and regulations as outlined above. It is time for Congress and the SEC to look beyond the tip of the iceberg if there is to be a fair and effective balance of regulation in the tender offer field. 